\title{
The Value of Certain Nutritive Elements to the Plant Cell. ${ }^{1}$
}

\author{
BY \\ HOWARD SPRAGUE REED. \\ With two Figures in the Text.
}

I. INTRODUCTION.

$\mathrm{T}^{\mathrm{T}}$ is my purpose to describe in the following paper the results of a study upon the rôle of certain essential elements in the physiology of the plant cell. Since the times of De Saussure and Boussingault it has been known that the complete development of the higher plants and of many of the lower ones requires soluble salts of ten different elements, each one of which possesses a relatively low atomic weight. Some of these elements, like iron and magnesium, are required only in small quantities, but a certain amount is indispensable to practically all plants.

The studies of such investigators as Wolf, von Raumer, Loew, and others, have shown that certain of these essential elements accomplish more or less definite functions in the growth and fructification of the plant. There is every reason to believe that the different essential elements also perform more or less definite functions in the physiology of the cell. However, we have much less scientific evidence upon the latter subject than upon the former. Molisch ('95), Bokorny ('95), and Loew ('92, '99), have furnished some valuable data upon this question.

The majority of the workers who have studied the rôle of the essential elements in plant metabolism have worked upon the assumption that the almost exclusive function of these elements is to furnish chemical compounds suitable for elaboration into plastic and aplastic materials and fluids of the plant. As a result of my experiments I feel justified in advancing the opinion that the inorganic food constituents of the plant may also indirectly perform functions of the greatest value to the plant without necessarily entering into the composition of any of its parts.

The plant cell is an especially favourable object for studying the rôle of the essential elements, because it takes its food in the form of comparatively

${ }^{1}$ Contribution I 5 from the botanical laboratory of the University of Missouri. A thesis presented to the Graduate Conference, 1907 .

[Annals of Botany, Vo1. XXI. No. LXXXIV. October, 1907.] 
simple compounds. The fact that the processes of metabolism in the plant cell are relatively slow, and permit of more exact observation than in the animal cell, makes the former a very favourable object of research.

De Saussure, in his classical 'Recherches chimiques sur la vegetation,' placed on record his observations and experiments, which proved that the ash of plants contains the same mineral nutrients which they drew from the soil. He showed that terrestrial plants draw their mineral nutrients from the soil in the form of aqueous solutions, and that the ash of seaweeds contains only the salts which are present in sea water. In certain respects De Saussure went far beyond his contemporaries. He succinctly states, for example, that plants do not absorb salts in the same proportion as they exist in the soil solution. He also recognized the ability of plants to utilize very dilute solutions of mineral nutrients.

\section{HISTORICAL.}

\section{Previous work upon the rôle of potassium.}

De Saussure, in the treatise already mentioned, established the necessity of potassium salts for the growth of terrestrial plants. Birner and Lucanus ('66), experimenting with oat plants in water cultures, gave the first proof that the element potassium is absolutely indispensable for flowering plants, and cannot be replaced by rubidium, caesium, sodium, lithium, or ammonium. The perfection of the water-culture method and consequent refinement of experimental methods enabled these investigators to obtain data of fundamental value. Their work was extended and confirmed by G. Wolf ('68), who attempted to establish Liebig's law of the minimum for plants grown in water culture. The results of Hellriegel ('67) on barley also confirmed the observations of Birner and Lucanus. Molisch ('96) showed that the related elements, rubidium, caesium, lithium, and sodium, could not be substituted for potassium in the physiology of Protococcus infusionum. Nobbe (' $\%$ ) seems to have been the first investigator to point out the necessity of potassium salts for the formation of carbohydrates in plants. Gaunersdorfer ('87) not only showed that lithium cannot be substituted for potassium but that it has a toxic action upon some plants.

Loew ('98 A) has shown that rubidium may replace potassium in the nutrition of certain of the lower plants. Also that rubidium exerts a stimulating action on plants when all necessary nutrients are present. Benecke ('07) has also stated that rubidium and caesium within certain limits may replace potassium in the nutrition of Bacillus fuorescens and of B. pyocyaneus.

In the presence of potassium, sodium has been shown also to produce increased growth in plants. Hellriegel ('98) found that plants grown in 
sand cultures succeeded better when both potassium and sodium were present than when only potassium was furnished. Dassonville ('98), who studied the effects of various elements upon the form and structure of plants, found that wheat plants were strongly lignified at the base of the stem when sodium was substituted for potassium. He believed that potassium retards the lignification of the mechanical tissues, and that sodium, playing a less active rôle, is less favourable for growth and more favourable for lignification. Sodium was less favourable than potassium for the formation of secondary roots of the tomato. When sodium was furnished the number and importance of the vascular elements in the epicotyl were diminished, the cells of the cortex were larger and the intercellular spaces smaller.

Wheeler ('05) has shown that the addition of sodium salts to a soil already fertilized with a greater or less amount of potassium salts increased the growth of such plants as beets, radishes, and flat turnips, but did not increase the growth of rye, chicory, carrots, spinach, and lettuce. The continued application of sodium salts in the absence of any potassium salts was not generally beneficial.

The foregoing investigations indicate that there may be functions which either sodium or potassium may perform, and other functions which only potassium may perform. Such investigations are unfortunately open to one serious objection because conducted in soil or sand cultures. The soil, like any finely divided solid, possesses specific powers of absorption, and would hold a certain amount of basic bodies (among them potassium) in an absorbed state. The addition of sodium salts would tend to liberate some of the potassium with consequent benefit to the plant. The soils also furnish a certain amount of potassium from the potassium-containing minerals which enter into their composition.

The work of Breazeale ('06) is not, however, open to such criticism because conducted in water cultures. Breazeale was successful in measuring the amount of different nutrients removed from a complete nutrient solution after being transferred from solutions in which some one element was lacking. He showed that plants which had previously grown in solutions lacking potassium usually withdrew more potassium, in proportion to their growth, from the complete nutrient solution than plants of the same age which had previously grown in a complete nutrient solution. Plants which had previously grown in solutions lacking sodium also absorbed more potassium than those previously grown in complete nutrient solutions containing both sodium and potassium. Finally he showed that plants which had previously grown in solutions lacking both sodium and potassium drew most heavily upon potassium when placed into complete nutrient solutions. These results, more than any others known to the writer, appear to give definite facts upon which the question of the possible value 
of sodium to the plant may be settled. They seem to point quite conclusively toward a possible utilization of sodium by the plant.

\section{Previous work upon the rôle of phosphorus.}

Ville ('61) appears to have been one of the first investigators to show conclusively that phosphorus is necessary for all plant-growth. Although his experiments were performed with sand cultures they show such definite results that there can be no doubt of his conclusions. He also showed that, in order to serve as a plant nutrient, the phosphorus must be in the form of phosphates.

Stoklasa ('96) and Molisch ('96) refuted the statements made by Bouilhac (94) regarding the possible substitution of arsenic for phosphorus. The first-named investigator showed that such a substitution was impossible for phanerogams, the second confirmed the evidence for certain Algae.

Berthelot and André ('88) studied the amounts of phosphorus in Amarantus caudatus at different times during the growing season, finding that the relative content of phosphorus was greatest in the young plant, and decreased continually to maturity. Although it is universally held that phosphorus in the form of inorganic or organic compounds is necessary for the growth of any plant cell, little knowledge is at hand concerning the rôle of phosphorus in the cell. Loew ('91) described the pathological conditions ensuing when Spirogyra cells were deprived of phosphorus. The cells studied ceased to grow although they continued for some time to form starch and proteid; the chloroplasts turned yellow, and fats and proteids accumulated in the cells. He also pointed out the importance of phosphorus for the formation of lecithin. He regarded lecithin as a body into which fat must be changed in order to become combustible in the protoplasm.

Becquerel ('04) found that moss spores would germinate and grow for about a month in nutrient solutions lacking phosphorus, but the protonema gradually lost its green colour and died.

Schoene ('06) reported the results of experiments upon the germination of moss spores in nutrient solutions lacking phosphorus. He observed that after sowing spores upon such deficient solutions that the oil content of the spore disappeared, and at the same time there were formed rodshaped chlorophyll bodies. In Funaria the oil globules disappeared as the protonema developed. The more rapid the formation of starch, the more rapidly did the oil content vanish.

\section{Previous work upon the rôle of calcium.}

Aside from the earlier ideas upon the value and function of nitrogen in the plant, the first ideas upon the specific functions of any one of the mineral nutrients appear to have been those of W. Wolf ('64). That 
investigator appears to have discovered, incidentally, that calcium salts have a stimulating action upon root growth. It has since been shown that other salts will produce the same effect, but Wolf's discovery appears as one of the first attempts to explain the unknown but beneficial action of calcium salts on certain soils.

Holzner ('67) assumed on very insufficient grounds that calcium salts are necessary for the formation of cellulose. He regarded calcium as the carrier of phosphoric and sulphuric acids in the plant, and believed that these acid radicals were replaced by that of oxalic acid when they reached cells in which proteid synthesis occurred. We have evidence now that this latter assumption must be regarded as untenable. G. Wolf ('68) first showed that the functions of calcium in the plant could not be performed by magnesium. Stohmann ('62) demonstrated the necessity of calcium in the formation of the green parts of the plant by cultivating corn plants in solutions lacking calcium. At the end of five weeks the plants were dead at the tips; after the addition of a small amount of calcium salts, the plants quickly took on new life and began forming new leaves and shoots.

Boehm ('75) seems to have been the first to discover any of the more important functions of calcium. He observed an abnormal accumulation of starch in plants (Phaseolus vulgaris) grown in water cultures lacking calcium; the accumulation of starch being in the pith and cortex of the lower part of the stem of the plants. He also found that calcium is necessary for the formation of new cell walls, although his idea of the mode in which calcium functions in cell-wall formation was probably incorrect. He believed that the function of calcium in the formation of cellulose walls was similar to its action in the formation of bone in animals. It was demonstrated by Molisch ('95) that this conception of the action of calcium was erroneous. Molisch showed that transverse walls in Spirogyra did not develop, or consisted only of imperfect septa when calcium salts were lacking, and that there was a non-formation of all parts. Boehm also found that the addition of calcium salts to distilled water prolonged the life of the plants which grew in it; but that when magnesium instead of calcium salts were added they exerted a toxic influence upon the plants.

The next work of importance upon the function of calcium appears to have been that of von Raumer and Kellermann ('80), which especially advanced the knowledge of the rôle of calcium in the transport of carbohydrates in the plant. Von Raumer ('83) carried their investigations still further and published them in a paper of fundamental importance. $\mathrm{He}$ seems first to have discovered the necessary ratio between calcium and magnesium. When plants were grown in distilled water, or in solutions lacking both calcium and magnesium, they made better growth than in solutions where only calcium was lacking. He showed that magnesium had a toxic action which could be counteracted by calcium. The plants (Phaseolus 
multiflorus) which he employed displayed, when grown in the absence of calcium, interruptions in the translocation of carbohydrates. When magnesium was lacking the chlorophyll bodies became unhealthy, and, as a result, the plants possessed an etiolated appearance.

Loew ('92) ascribed a highly important function to calcium. $\mathrm{He}$ regards calcium as one of the important mineral bases which enter into the constitution of the proteids composing the cell nucleus and chlorophyll bodies. According to his interpretation these proteids take up magnesium in the absence of calcium, and the resulting magnesium-proteid compound has not the same well-defined capacity for imbibition and other processes which the calcium-proteid bodies possess. Hence the harmful effects observed when plants grow in a calcium-free medium which contains magnesium. Loew verified the observations of Boehm and von Raumer that solutions of pure magnesium salts have a toxic action, and ascribed it also to the harmful substitution of magnesium for calcium in the proteids. Bokorny ('95) repeated and confirmed many of Loew's experimental data. Unfortunately this theory fails in the case of a group of plants which form considerable amounts of proteid, viz., the Fungi. It is well known that the members of this group of plants are able to reach maturity and form reproductive bodies in the entire absence of calcium. More conclusive evidence would seem to be needed to establish the calcium-proteid theory.

In their study of Phaseolus plants grown in water cultures, von Portheim and Samec ('05) obtained results which afford some support for the calciumproteid theory. They found by analysis that normal plants contained much more calcium than magnesium ; but plants grown in solutions lacking calcium had a much greater proportion of magnesium than the normal plants. In pathological conditions induced by the absence of light, the amount of magnesium in the plant was nearly equal to the calcium, although the plants were supplied with a complete nutrient solution. The fact that the plants deprived of calcium took up more magnesium strengthens Loew's assumption of the calcium-proteid compound, yet it will require further investigation to determine whether this additional magnesium may not find use in other ways in the plant. Haselhoff ('93) showed that strontium was unable to replace calcium in water cultures of Vicia and Zea. Loew ('98) and Suzuki ('00), have also shown that the functions of calcium cannot be performed by strontium or barium.

The neutralizing action of calcium in the synthesis of proteids has been taken up anew by Yermakov ('05) in connexion with the assimilation of nitrates. This author assumed that since ammonia and oxalic acid are formed when nitric acid acts upon glucose, that a similar reaction might occur in the synthesis of proteid in the plant. If this assumption were true, the oxalic acid formed would not be neutralized in the absence of calcium salts, and being injurious to the plants would hinder the assimi- 
lation of nitrate nitrogen. Experimental data verified such an assumption. Leaves which were supplied with calcium salts were able to assimilate nitrates, but where no calcium salts were furnished the nitrate remained unaffected.

Schimper ('88) concluded from a study of the green parts of the plant that the principal function of calcium was to precipitate oxalic acid and soluble oxalates. As the same author found (Schimper, '90) in a subsequent research that calcium is not always present in the meristem, he assumes that potassium may sometimes take the place of calcium in neutralizing oxalates.

Groom ('96), from a study of interrupted carbohydrate translocation in the absence of calcium, concluded that the presence of acid potassium oxalate is inhibitory to the action of diastase. This hypothesis is strengthened by the observation of Hammersten ('96) on the need of calcium salts for the formation of blood clots. Calcium salts appear to play a specific part in forming blood clots which is hindered by the alkali oxalates. It is quite possible that this action stands in the closest relation to the formation of the fibrin ferment.

Additional data have recently been presented by Grafe and von Portheim ('06), which confirm the idea that part of the injury caused by the absence of calcium is due to the interference in carbohydrate transformation and transfer. These investigators found that the addition of levulose, dextrose, or saccharose to calcium-free solutions enabled Phaseolus plants to live in them for a longer period than in calcium-free solutions containing no sugars.

Kraus ('97) brought out evidence on the other hand that the importance of calcium does not depend primarily upon its power to precipitate soluble oxalates since some plants are able to tolerate the presence of oxalic acid in their tissues. He found that the supply of calcium oxalate in the rhizomes of certain plants was drawn upon when other sources of calcium were gone. Loew ('98) also doubted the necessity of calcium to neutralize oxalic acid; but Bruch ('02) has gone farther and shown that the Gramineae and some other plants can endure relatively large amounts of oxalates. Between concentrations of 278 and 18 parts per million of oxalates wheat plants grew to the period of blossoming (seven weeks). In that length of time all the oxalates furnished them had vanished, although it is possible that micro-organisms in the cultures may have aided in their destruction. He found that wheat could be grown in distilled water containing calcium oxalate and in nutrient solutions where calcium sulphate was replaced by calcium oxalate.

In view of these facts the necessity of calcium to neutralize oxalic acid does not seem to be as imperative as was held by Schimper, Groom, and others. 


\section{Previous work on the rôle of magnesium.}

Boehm ('75) seems to have been almost the first one to point out any specific action of magnesium salts upon plants. It was quite natural that he should have discovered the toxic action of magnesium salts in solutions when he attempted to use these salts in water cultures. Von Raumer ('83) went further and pointed out the antidoting power of calcium for magnesium, and the ratio of the two elements necessary for the best growth of plants. He observed that Phaseolus plants suffered characteristic injury when grown in the absence of magnesium. After becoming about one meter high the internodes of the plants ceased to elongate, and the new leaves remained small and chlorotic.

The apparent toxic qualities of magnesium salts have already been mentioned in discussing the action of calcium salts, but other considerations necessarily come up at this place. Loew holds the view, previously mentioned, that magnesium salts cause injury as a result of displacing the calcium ions from certain important proteid compounds, and that the resulting magnesium compound is not capable of performing the normal functions necessary to the continued existence of the living tissues. According to his view a proper ratio of calcium and magnesium salts should be afforded, if the normal processes of the cell are to continue.

In this regard the recent paper by Duggar ('06) is of value. In a careful study of the toxic action of various salts added to sea water, he found that magnesium salts had a very low toxicity for marine algae. Granting, as we must, in the light of our present knowledge, that the marine algae are able to withstand much greater concentrations of magnesium salts than fresh water algae, or phanerogams, it is difficult to see how this great group of plants (some of them possessing a truly high organization) conforms to the general statements made by Loew, concerning the replacement of calcium by magnesium in the hypothetical calciumproteid compound. Duggar found that ammonium salts had a greater toxic effect than any other basic radical which is ordinarily regarded as a nutrient for an autotrophic plant. Arranged in the order of their toxicity for marine algae, his paper gives the series $\mathrm{NH}_{4}, \mathrm{~K}, \mathrm{Ca}, \mathrm{Mg}$. He states further, "The very low toxic effect of the neutral magnesium salts upon the marine algae makes it evident that these plants are very notable exceptions to the rule which Loew and others have found to hold in the nutrient relations of a few fresh water algae and many phanerogams.' The great preponderance of magnesium over calcium in the experiments made by Duggar shows that the protoplasm of these plants is not seriously injured by magnesium. ${ }^{1}$

${ }^{1}$ Loew has suggested that such plants are able to withstand large amounts of magnesium on account of the acidity of the cell sap. It is difficult to see how the acidity of the cell sap can 
It would seem that this power of calcium is that of a specific antidote for magnesium, just as specific antidoting properties have been demonstrated between various other elements.

The antidoting power of calcium was demonstrated by Kearney and Cameron ('02). In an extensive series of experiments they found that calcium nearly always had marked ability to decrease the toxicity of both magnesium and sodium salts for seedlings of Lupinus albus. Krönig and Paul ('97) have shown that a similar marked decrease of toxicity for bacteria was obtained when the chloride of sodium, potassium, magnesium, zinc, or cadmium was added to a solution of mercuric bichloride. Clark ('01) demonstrated that the toxic value of mercuric bichloride for fungi was greatly diminished by the addition of sodium chloride or hydrochloric acid. Pigorini ('07) has even been able to show that such a poisonous substance as sodium thiosulphate was able to diminish the toxicity of silver nitrate solution for Carassius auratus. True and Gies ('03) have shown that the toxicity of salts of the heavy metals to seedlings is greatly reduced by the addition of salts of sodium, magnesium or calcium. Loeb ('06) has found that the effect of magnesium in producing rhythmical motions in a jelly-fish may be inhibited by the addition of an equivalent amount of calcium or potassium to the water. Osterhout ('06) has reported that pure sodium chloride solutions are quite toxic to certain marine plants. The toxicity is much diminished if calcium chloride be added, and is still further diminished if both calcium and potassium chlorides be added to the sodium chloride solution.

While it is no doubt true that a very large number of plants require that some sort of a ratio between calcium and magnesium be maintained, it is difficult to fit the theory of the necessary calcium-proteid compound to a vast number of plants, which normally live with little or no calcium. It seems more plausible to postulate (and at present it appears impossible to do more) that calcium salts are able to perform some specific antidoting powers against magnesium in the plant. There appear to be instances where the antidoting may be performed by sodium, or by potassium as well as by calcium. Future investigation will have to determine the nature of this antidoting power.

Mayer ('69), Raulin ('69), and Winogradsky ('84) demonstrated that yeast and certain other fungi could grow in the absence of calcium, but required magnesium. Molisch ('95) showed that the same requirements held for Microthamnion, Stichococcus and some other Algae. Sestini ('91) showed that the functions of magnesium could only be imperfectly performed

make any particular difference to these or any other plants unless, indeed, it be proved that phosphoric acid is relatively abundant. On the other hand it is possible that the comparatively large amount of sodium present in the sea water might act as a partial antidote for magnesium. 
by beryllium, although this element may be absorbed in rather large quantities.

Loew ('92), in discussing the rôle of magnesium in the plant, set forth the hypothesis that one of its functions was to serve as a carrier for phosphoric acid. On account of the readiness with which magnesium salts are dissociated, they would present the phosphoric acid radical in a form favourable for assimilation. The results of numerous analyses can be cited to show that magnesium is usually abundant in the plant where nucleoproteid is being formed. If magnesium has such a function, it is evident that a small quantity of magnesium could be used for a great deal of work, since it may serve repeatedly as a carrier of phosphoric acid to the cell. This would also explain such an observation as that of von Raumer, that Phaseolus plants were able to grow to a height of one meter when they were supplied only with the magnesium stored in the seed.

Bokorny ('95) practically duplicated Loew's results upon different algae. In addition, he stated that the nuclei of cells which had lived in solutions lacking magnesium were smaller than those of the cells in control cultures. His observations were principally upon the modifications produced in the nuclei and chloroplastids.

\section{The TeChnique of Experimentation.}

The experimental study described in the following pages was entered upon in the year 1904, in the botanical laboratory of the University of Missouri. To Professor B. M. Duggar, under whose general oversight this investigation has been prosecuted, I wish to extend my heartfelt thanks for his uniform kindness in freely giving advice, suggestion, and kindly criticism of immeasureable value. Any adequate expression of my indebtedness to him is impossible. I wish also to express my sincere gratitude to Professor Waldemar Koch for valuable suggestions, and for material which he so generously placed at my disposal.

\section{Choice of suitable plants for cultures.}

In choosing material suitable for a study of the action of different elements in cell metabolism, I found it desirable to take those plants which would admit of microscopical examination in the living condition. For certain purposes it was also necessary to employ plants which contained a minimum of reserve food substances. With these and other considerations in view I have employed different species of filamentous Algae, the protonema of moss, the young prothalli of ferns, the root-tips of phanerogamic plants, and the filaments of Basidiobolus ranarum. The filamentous thalli of the algae could be advantageously studied in the living condition under the microscope, and the species of Spirogyra employed were readily fixed 
stained and converted into permanent preparations for more detailed study. The same was true of the prothalli of the ferns employed. The root tips of young chlorophyll-bearing plants which were always grown in, water cultures were studied only after being fixed, sectioned and stained. The filaments of Basidiobolus yielded little when studied in the living condition, but when fixed and stained they permitted of accurate study with the higher powers of the microscope.

With each plant experiments were conducted which were designed to show the rôle of certain elements in the physiology of the cell. This was accomplished, in most cases, by using a series of solutions which lacked, in turn, one of the essential elements ; the missing radical being replaced by a non-essential and non-toxic (at least at the concentration employed) radical. After living in the deficient solution for a varying length of time, depending both upon the nature of the plant employed and the purpose of the experiment, the plants were studied microscopically and compared with the cells of a like plant which had lived for a similar time and under exactly similar conditions in a complete nutrient solution.

\section{Preparation of nutrient solutions.}

In preparing the nutrient solutions, little difficulty was experienced in obtaining chemically pure salts of the standard chemicals.

A supply of pure non-toxic distilled water was not, however, always easy to obtain. Ordinary distilled water is seldom suitable for physiological work, because it contains traces of the metals which compose the distilling apparatus. Usually copper is employed in some form in the construction of the apparatus, and the traces of this metal in the distilled water have been recognized as sources of error for some time. The use of block tin apparatus reduces the amount of metallic material in distilled water to practically nil. Apparatus of glass was used in most of the redistillation which I performed, but since the alkali silicates are quite soluble, the water obtained from such apparatus contained more or less alkali salts.

Alkaline permanganate was usually added to the distilling flask; and a satisfactory grade of distilled water was usually obtained. While the experimental work was still in progress, a method was devised by Livingston ('07) which gives a non-toxic distilled water. By the use of a finely divided solid, substances are removed by absorption which are extremely difficult to remove by distillation. To obtain such physiologically pure water, I used freshly prepared ferric hydroxide, as an absorbing agent, which was made by adding ammonium hydroxide to a hot solution of ferric chloride so long as a precipitate was formed. The excess of ammonium hydroxide was boiled off, and the ferric hydroxide was filtered out. The precipitate was thoroughly washed on the filter with hot water. About $35^{\circ} \mathrm{cc}$. of the moist ferric hydroxide was added to a bottle con- 
taining $\mathrm{I}, 500 \mathrm{cc}$. of redistilled water, and shaken for several minutes. The bottle was allowed to stand until most of the ferric hydroxide had settled to the bottom, then the supernatant water was passed through a filter paper and used for making up solutions. ${ }^{1}$

When stock solutions were necessarily kept for some length of time, they were stored in flasks of Jena glass closed with rubber stoppers. Where I desired to cultivate plants in the absence of potassium, the glass-ware to be used for the cultures was filled with a solution of potassium hydroxide. After standing for several weeks, the glass-ware was thoroughly washed out with water, and steamed for several hours in an Arnold sterilizer. By means of this treatment it is believed that the error of experiment due to soluble bases in the glass was reduced, but not entirely eliminated. It has been shown by Kohn ('05) and Benecke ('07) that the growth and pigment formation of certain bacteria is influenced by small amounts of the essential elements contained in the glass. It need not be assumed, however, that the growth of algae or of phanerogams would be as greatly influenced by the presence of these salts, as bacteria have been shown to be. I tried to use vessels lined with a coating of paraffin as described by Molisch ('95), but without success. The paraffin contained petroleum products which had a toxic effect upon the plants.

The solutions for experiments were prepared by mixing proper quantities of the stock solutions, and diluting to the proper concentration.

${ }^{1}$ My experiments with water prepared in this manner confirm the experience of Livingston ('07) that such distilled water gives a superior growth of plants when used as the basis for a culture solution. These results are in harmony with the work of Lyon ('04) in which he found that tapwater which was decidedly toxic to Arbacia eggs was much improved by boiling away one-third of its volume. When the water was distilled from glass into glass the first, second, and third tenths of the distillate exhibited toxic properties, the fourth portion was of good quality. The best quality of distilled water was obtained by distilling in glass with potassium bichromate and sulphuric acid added to the contents of the retort. A theory has recently been propounded by Schreiner and the writer ('07) to explain the toxic properties of some distilled waters. It has been shown that even when distilled in glass apparatus many soil extracts give water unsuitable for the growth of plants. This is probably due to the existence of toxic substances in the soil extract which are volatile and pass over with the water vapour. These toxic substances may often be boiled off with resulting improvement to the soil extract. All waters from wells, springs, rivers, or lakes are virtually soil extracts. Upon distillation the volatile toxic substances may pass over with the steam, are condensed, and appear in the distillate. It is true that repeated distillation in the presence of active oxidizing or reducing agents will remove such substances, but they are more easily and innocuously removed by treatment with an absorbing agent like ferric hydroxide. Rain-water gathered in glass vessels is not toxic to plants. This good quality is to be accounted for by the fact that such water remains for some time in the vapour condition, and as such is subjected to the action of air, light, and other agents capable of effecting oxidation. The action of these agents is probably the same as that of the oxidizing agents added to the retort of the distilling apparatus. 


\section{Advantages of certain formulae for nutrient solutions.}

In the first experiments upon algae and fern prothalli, I used the wellknown formula of Knop in making the nutrient solution:-

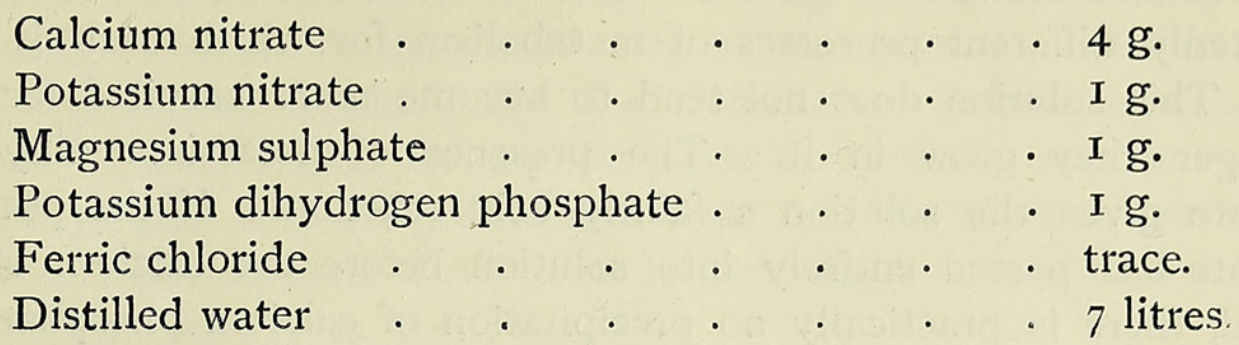

Repeated trials of this solution agreed in showing that it is unsuited for the growth of algae. A large quantity of nitrate is supplied in the form of calcium nitrate. The algae use the nitrate more rapidly than the calcium. As a result, the solution continually increases in alkalinity, and thereby becomes less and less suitable for the growth of Algae. A neutral or slightly acid medium is more favourable for the development of most algae, and this condition was fulfilled in the original solution by the presence of the potassium dihydrogen phosphate. Unfortunately this condition is not maintained after the plants begin to grow, because the nitrate is removed from calcium nitrate, resulting in alkalinity due to calcium carbonate formed with the carbon dioxide always present in such cultures. The lower algae will thrive, as Molisch ('96) stated, in a slightly acid medium, and it is probable that the higher algae grow best when the solution is near the neutral point. Klebs ('96) found that a distinctly alkaline culture solution was necessary for the formation of zoospores in Vaucheria. The conditions favouring vegetative growth were not determined with respect to acidity.

After discarding Knop's formula, I employed the following modification of a formula of Beijerinck given by Moore ('03):-

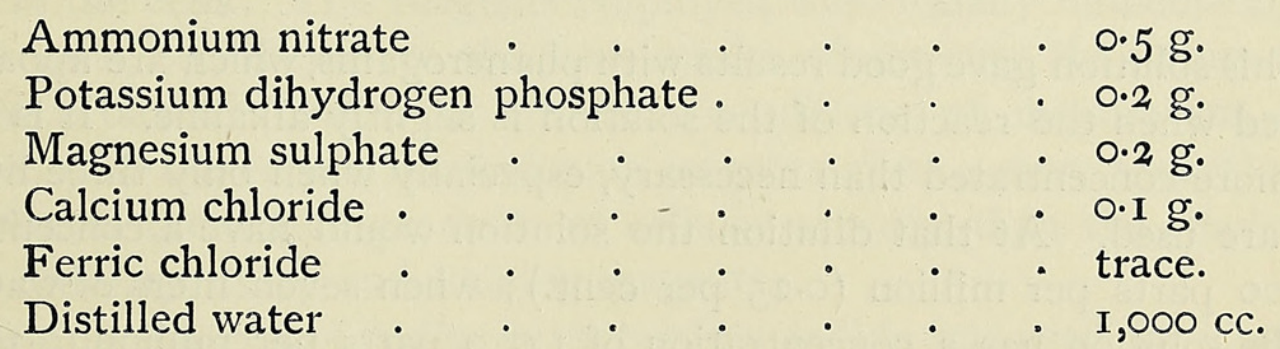

The nutrient solution when made according to this formula, has a concentration of 1,000 parts per million ( 0.1 per cent.). This concentration is greater than necessary, in fact is much greater than that to which most plants are accustomed in nature. Though a more dilute solution would undoubtedly serve just as well, I have not made any attempts to determine the limits of concentration for optimum growth.

This formula proved to be eminently satisfactory for the growth of 
algae, moss protonema, and fern prothalli. Ammonium nitrate appears to be a very suitable form in which to supply a source of nitrogen. The plant probably derives benefit sooner or later from the reduced form of nitrogen as ammonium, as well as from the oxidized form as nitrate. There are undoubtedly different processes of metabolism for which each is better suited. This solution does not tend to become more unsuited for algae, the longer they grow in it. The presence of potassium dihydrogen phosphate gives the solution a faintly acid reaction. If the potassium phosphate has passed entirely into solution before the calcium chloride is added, there is practically no precipitation of calcium phosphate until heat is applied in the process of sterilization. This precipitate did not prove troublesome, however, because the solutions were measured out before being sterilized, and errors in measurement due to the presence of a solid substance were avoided. The calcium is furnished as calcium chloride in a much smaller quantity than in the solution of Knop. This smaller amount must be regarded as more rational if we regard the needs of the plant. As the calcium radical is used more rapidly than that of chlorine, the solution tends to become slightly more acid, and the conditions are correspondingly better for algae.

The nutrient solution which was used in the cultivation of phanerogams was one given by Pfeffer (Physiology of Plants, English trans., vol. i, p. 420) :-

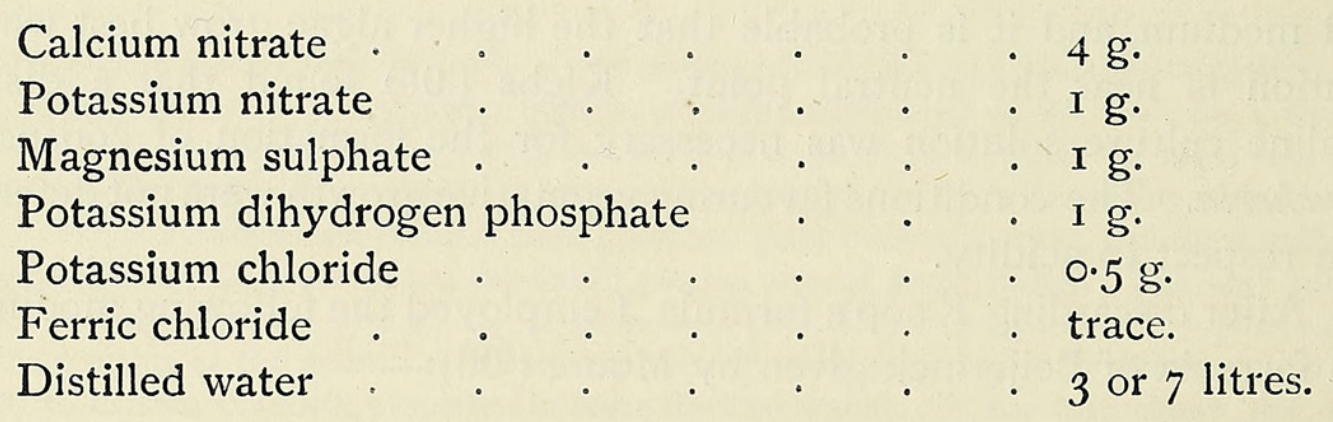

This solution gave good results with phanerogams, which are apparently favoured when the reaction of the solution is slightly alkaline. It is somewhat more concentrated than necessary, especially when only three liters of water are used. At that dilution the solution would have a concentration of 2,500 parts per million ( 0.25 per cent.); when seven liters of water are used the solution has a concentration of $\mathrm{I}, 070$ parts per million ( 0.107 per cent.). This solution is somewhat more concentrated than necessary for the growth of higher plants. Indeed, the work of Breazeale ('05) indicates that the optimum concentration of salts for wheat plants in water culture is approximately 300 parts per million.

The volume of the solution employed in cultures was always made large. The advantages of a large volume are numerous; the concentration of the solution is altered more slowly as the plants remove the nutrients; 
again, the deleterious products which arise as excretions are more highly diluted, and hence less harmful to the plants.

When placed in the culture flasks the solutions were sterilized with steam in an Arnold sterilizer. A single heating lasting about forty minutes was usually sufficient for the sterilization of the aqueous solutions.

The media upon which the Basidiobolus was grown require special mention. I found that for my purposes an aqueous medium was unsatisfactory, and was obliged to add agar agar to all nutrient solutions employed. The formula first used is one which is commonly used in physiological work with the Fungi:-

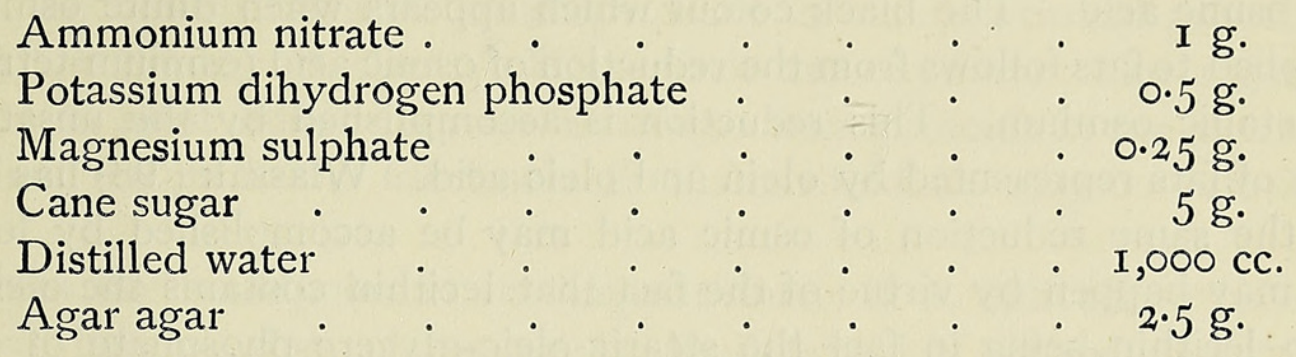

The growth of the fungus on this culture medium was not entirely satisfactory, since the palmella stage described by Raciborski ('96) is produced when sugar is supplied as a source of carbon. The filamentous stage was produced when starch instead of sugar was supplied as the source of carbon. I prepared a paste by cooking in an Arnold sterilizer I I 5 grams of clean chopped potato in $400 \mathrm{cc}$. of distilled water. The inorganic salts and agar were dissolved in this paste in the same proportions given above. This gave a medium upon which Basidiobolus produced good filaments.

\section{Microchemical Methods.}

In examining living cells under the microscope, it was often necessary to apply some reagent in order to determine the nature of the substances found in the cells. The reagents employed were usually immediately fatal to the cells, but they were the best means of showing the nature of substances produced under the different conditions of metabolism. It is believed that the employment of such reagents gives a more accurate representation of the actual products of cellular activity, than the employment of the ordinary fixing and staining reagents.

Gram's solution of iodine in potassium iodide was used for identifying starch and erythro-dextrin. With the latter it gives a diffuse red-pink colour which can be observed microscopically.

The identification of albuminous substances was rather uncertain when the biuret test was used, because the colour was never deep enough to be very intense, and hence difficult to observe with the microscope. For microchemical work, I found the method described by Loew and Bokorny ('89) to be more satisfactory. The method as I employed it was as follows : 
the living cells to be examined were placed in 0.1 per cent. ammonium hydroxide for one hour, then into a Io per cent. solution of potassium ferrocyanide containing 5 per cent. acetic acid. The mixture was always freshly prepared by mixing equal quantities of 20 per cent. potassium ferrocyanide, and to per cent. acetic acid. The cells remained in this mixture for twelve hours, and were then washed in distilled water until the washings no longer gave a blue colour with ferric chloride. They were then placed in a 3 per cent. solution of ferric chloride for twelve hours. After this treatment the albuminous materials were coloured deep blue.

In testing for fats I did not rely upon the usual application of one per cent. osmic acid. The black colour which appears when dilute osmic acid is applied to fats follows from the reduction of osmic acid (osmium tetroxide) to metallic osmium. This reduction is accomplished by the unsaturated series of fats represented by olein and oleic acid. Wlassak ('98) has shown that the same reduction of osmic acid may be accomplished by lecithin. This may happen by virtue of the fact that lecithin contains the oleic acid group, lecithin being in fact the stearic-oleic-glycero-phosphate of cholin, and in the presence of water some oleic acid is probably formed. This is in accord with Wlassak's observation that pure lecithin readily stains with osmic acid if previously kept for a time in water. Wlassak also pointed out that while osmic acid stains both fat and lecithin, the method of Marchi stains only the fat. This is because the lecithin loses its power of reducing osmic acid if it is kept for some time in a solution of potassium bichromate, while olein does not. Halliburton and Mott ('02) have given this subject further study, and point out the probability that when potassium bichromate acts upon lecithin it oxidizes the oleic group. When osmic acid is applied to such a preparation it is not reduced, and hence the preparation does not blacken. In practice I found it best to put the plant tissues directly into Erlicki's fluid, and allow them to 'harden ' five to seven days at room temperature. Subsequently they were treated with one per cent. osmic acid.

Although no extensive experimentation was attempted with stains and mordants, a few were of sufficient merit to deserve mention.

Excellent results in staining Algae were obtained with iron-alum-haematoxylin and with safranin. The safranin stain was much improved when the filaments were previously mordanted in potassium permanganate according to the method of Henneguy.

In staining the protonema of mosses and the prothalli of ferns, the best results were obtained by using a modification of Hartog's nigrosin and carmin method. ${ }^{1}$

1 The process is as follows:-(1) The living material is put for forty minutes in 50 per cent. alcohol containing glacial acetic acid equivalent to two per cent. of the entire volume. (2) After briefly rinsing in $5^{\circ}$ per cent, alcohol, the material is stained thirty to forty minutes in Grenacher's 
For staining the microscopical sections of root tips, the best results were obtained from the use of Mann's Eosin and Toluidin Blue, according to a method which I have described elsewhere (Reed, '04).

\section{Data obtained From Experimental Work.}

\section{Experiments upon the rôle of potassium.}

The paramount importance of potassium for the production of carbohydrates in the plant, as well as for the synthesis of proteids, renders its study of primary interest. My results agree with those of other investigators in showing that potassium is indispensable for the continued growth and normal functioning of plants. Even when carbohydrates, like sugar, are supplied to most Fungi, they are unable to form proteids in the absence of potassium, except in the few instances where rubidium may be substituted for it.

From the standpoint of the experimenter, it is difficult to ascertain what will happen when plants are totally deprived of potassium salts. In the first place there is always a small amount of potassium in some form in the seed or spore from which the plant originates. Knowing, as we do, the power of the plant to use repeatedly the same supply of potassium for different purposes, one must not disregard the value of a small supply of that element. In the section of this paper dealing with methods, it has been already indicated that the small amount of potassium in the glass-ware which is continuously soluble is capable of partially supplying the needs of the plant grown in a culture solution in a glass vessel.

In a series of cultures of moss protonema where potassium was purposely omitted from part of the solutions, I eliminated, so far as possible, the amount of potassium originally present. Specimens of a moss (Atrichum sp.) bearing mature sporogonia were collected in January. They were kept in a dry condition in the laboratory until March 9, when they were used in making cultures. By means of sterile pincers and needle, the contents of mature capsules were scraped out upon a sterile slide, and at once transferred to the culture solutions. The cultures stood before an east window in light of moderate intensity, where the temperature ranged between $8^{\circ}$ and $15^{\circ} \mathrm{C}$.

At the expiration of a month the spores in the control cultures were found to have germinated, and to have produced healthy green protonemata varying from 2 to 5 millimeters in length. The filaments of the protone-

borax carmin. (3) It is then stained for two and one-half to three hours in a strong blue-black solution of nigrosin in 50 per cent. alcohol which contains acetic acid equivalent to 5 per cent. of the entire volume. (4) Decolorization is effected with 70 per cent. alcohol; (5) then dehydrate with absolute alcohol, clear in clove oil and mount in balsam. If the amount of material is small the first two processes may be carried through on a slide, but the third is best done in a watch-glass or other covered receptacle. 
mata were profusely branched, and showed evidence of rapid growth. The cells were filled with bright green chlorophyll bodies which contained starch. The spores in the solution in which sodium had been substituted for potassium had germinated, but none of the protonemata had grown to a length exceeding twice the diameter of the original spore. Starch could not be demonstrated. In solutions where no other metal of the alkali group had been substituted for potassium, ${ }^{1}$ none of the spores had germinated, nor even shown the characteristic green colour which precedes germination.

Two months after setting up the cultures, the results were found to bear practically the same relations to each other. The protonemata in the complete nutrient solutions had made excellent growth. The cultures in which sodium had been substituted for potassium showed a great many spores which had germinated, and produced moderately well developed protonemata. The protonemata in this solution had a very characteristic appearance, owing to the fact that most of the individual cells were short and swollen, giving the filaments a moniliform appearance (see figure $\mathrm{r}$ ). The lack of potassium did not appear to be detrimental to the development of chlorophyll, but I was unable to demonstrate the presence of starch in any of the chloroplastids.

The outcome of these experiments seems to indicate quite clearly that although potassium is absolutely essential for the proper functioning of all the processes of metabolism in the cell, there are certain processes which may go on when potassium is present in sub-minimal amounts, provided that sodium is also present. The germination and partial development of the moss sporelings illustrates this principle. When no sodium was supplied it was found that there was still less growth than where sodium was substituted for potassium. Further illustrations of this principle are shown by the work of Breazeale ('06) upon the higher plants. Another indication that the sodium is of some value is shown by the work of Becquerel ('04), who found that spores of Hypnum velutimum would germinate and grow for a time upon nutrient solutions containing no potassium salts. That there are some biological factors which play a part in this problem, is

1 The solution in which sodium was substituted for potassium had the following composition :-Sodium nitrate . . . . . $0.5 \mathrm{~g}$.

Sodium dihydrogen phosphate . $0.2 \mathrm{~g}$.

Magnesium sulphate . . . $0.2 \mathrm{~g}$.

Calcium chloride . . . . O.I g.

Ferric chloride . . . . . . trace

Distilled water . . . . . I,000 cc.

The solution in which neither sodium nor potassium were furnished had the composition :-

Ammonium nitrate . . . . $0.5 \mathrm{~g}$.

Diammonium hydrogen phosphate . $0.2 \mathrm{~g}$.

Magnesium sulphate ... $0.2 \mathrm{~g}$.

Calcium chloride. . . . . O.I g.

Ferric chloride . . . . . trace

Distilled water . . . . . I,000 cc. 
indicated by the fact that Becquerel was able to germinate spores of Hypnum velutinum on potassium-free solutions, but not spores of Atrichum undulatum.

The results of my experiments also show that potassium is intimately connected with the formation of carbohydrates, and that the lack of starch is not simply due to a pathological condition, because the chloroplastids remained normal for two months, and even increased in numbers. Evidently the sub-minimal amount of potassium was sufficient for the manufacture of the proteids necessary for the formation of plasmatic material. This phase of the cell's activity will be treated more fully in succeeding paragraphs.

The relation between potassium and starch formation was also studied by cultivating prothalli of Gymnogramme sulphurea upon the surface of

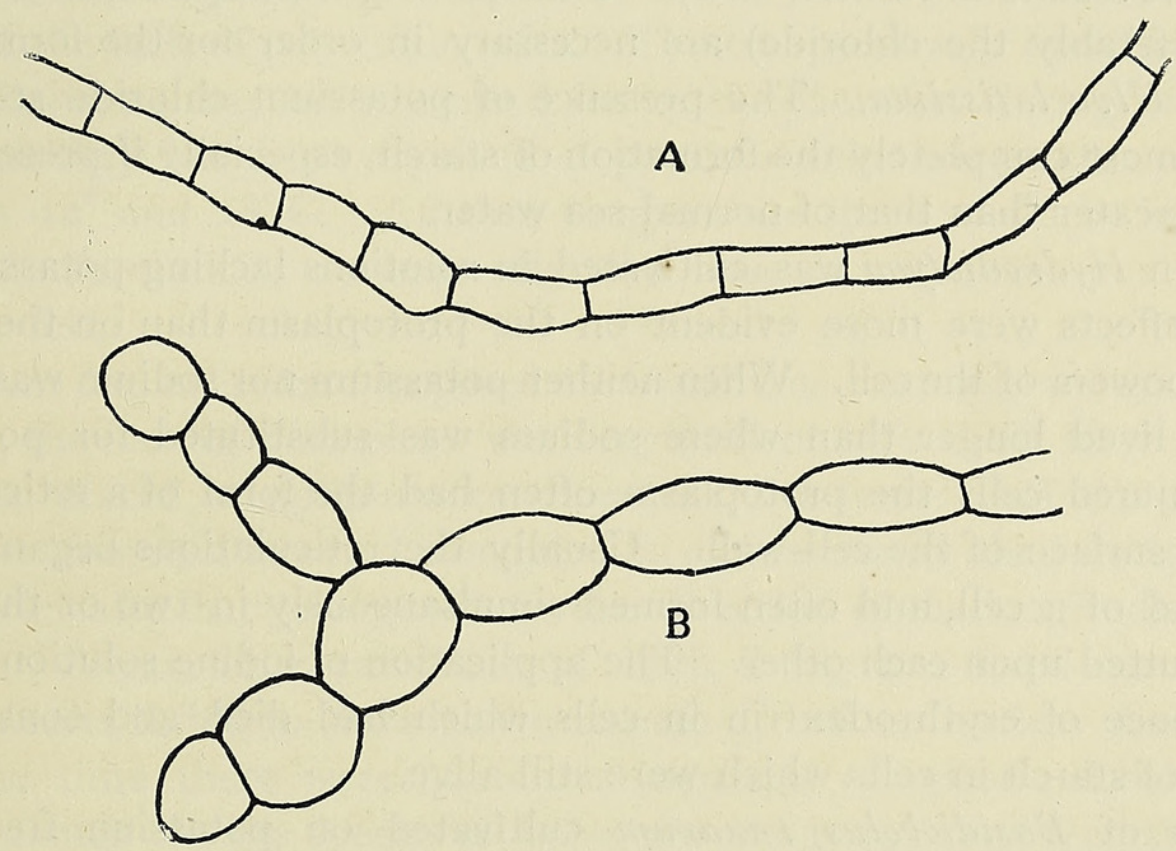

FIG. I. Effect of absence of potassium on cells of Moss protonema. A. Filament from a complete culture-solution. B. Filament from a culture-solution lacking potassium. Drawn with aid of a camera lucida. Same scale of magnification used in both cases.

nutrient solutions. On April 15 I made cultures in solutions lacking potassium. In part of them sodium had been substituted in an amount equal to the potassium taken out, in others neither sodium nor potassium was present. Spores were also placed in dishes of full nutrient solution, and in dishes of distilled water. At the expiration of eighteen days, all the spores except those in distilled water had germinated and grown out into short filaments. In the distilled water cultures there were no evidences of growth beyond the formation of a few rhizoids. At the end of thirtythree days the prothalli in all solutions lacking potassium were much alike. At the end of three months there was noted a slightly better growth in the 
cultures where sodium had been substituted for potassium than where neither one was present. The plants appeared to have obtained sufficient potassium from the glass vessels to enable them to grow and form chloroplastids, but they were devoid of starch.

Selecting a dish containing prothalli growing in a solution containing neither potassium nor sodium, and hence devoid of starch, I added a few drops of a I per cent. solution of potassium phosphate. When examined eleven days later, they were found to contain a large amount of starch. This experiment also goes to demonstrate the necessity of potassium for the formation of starch in the cell, although that cell may contain healthy, growing chloroplastids.

While it would be unsafe to apply in toto the conclusions obtained from the study of marine Algae to that of fresh-water Algae, it is interesting to note the results of Arber ('01 $a$ ). This investigator reported that sodium salts (preferably the chloride) are necessary in order for the formation of starch in Ulva latissima. The presence of potassium chloride seemed to inhibit almost completely the formation of starch, especially if present in an amount greater than that of normal sea water.

When Hydrodictyon was cultivated in solutions lacking potassium, the harmful effects were more evident on the protoplasm than on the starchforming powers of the cell. When neither potassium nor sodium was present the cells lived longer than where sodium was substituted for potassium. In the injured cells the protoplasm often had the form of a reticulum on the inner surface of the cell-wall. Usually the reticulations began to form at the end of a cell, and often formed simultaneously in two or three cells which abutted upon each other. The application of iodine solution showed the presence of erythrodextrin in cells which had died, and considerable amounts of starch in cells which were still alive.

Cells of Basidiobolus ranarum cultivated on potassium-free media exhibited protoplasmic structures which were distinctly more vacuolate than those of the control cultures. The nucleoli were less distinct than those of the control cultures.

In another experiment Zygnema filaments were cultivated in solutions lacking potassium. The pyrenoids of the chloroplasts rapidly lost their starch, and at the end of eight weeks the chloroplasts themselves showed signs of serious injury. The chloroplasts had become intensely vacuolated and the radiating fibrillae of protoplasm which normally suspend them had disappeared.

Instructive results were obtained from the study of cells which had been stimulated to divide karyokinetically in the absence of potassium. It is well known that cells in the filaments of Spirogyra may be stimulated to divide by exposing them to a low temperature in the dark, and then transferring them to optimum conditions of heat and light. The cultures 
I used were placed in a refrigerator at a temperature of 5 to $10^{\circ} \mathrm{C}$. during the night. The next morning they were removed and placed before a window in strong diffuse light at a temperature of $22^{\circ}$ to $25^{\circ} \mathrm{C}$. After two or three hours there was usually little difficulty in finding numerous cases of mitosis in the control cultures. Five hours after the material had been taken from the refrigerator, most of the mitotic divisions were completed, and the new cell-wall entirely formed.

In carrying out these experiments I chose cultures of Spirogyra which had grown for thirty-five days in the absence of potassium salts, together with a number of control cultures which had grown for an equal length of time in complete nutrient solution. Both series of cultures were subjected to conditions which induced mitotic divisions in the control plants. The filaments in the potassium-free cultures appeared to be in a living condition, although by the absence of starch it was plainly to be seen that they felt the lack of potassium salts. The comparatively healthy condition of the filaments may be accounted for by the fact that during much of the time that they had been deprived of potassium the temperature had been between $12^{\circ}$ and $18^{\circ} \mathrm{C}$. At that temperature there would be less activity in starch formation, consequently the absence of potassium was less severely felt.

When the cells were exposed to conditions normally inducing mitotic division, the lack of potassium was very evident. A short time after they had been placed in optimum conditions it was found that the cells in the potassium-free solution had elongated to at least twice their normal length. The nuclei also had elongated in the direction of the longitudinal axis of the cell. A careful examination of both living and fixed material from these cultures failed to show any instances of cell or nuclear division. At the same time there were numerous instances of mitotic division in the control plants. In the species of Spirogyra which was employed the average length of the cells was between 0.4 and $0.5 \mathrm{~mm}$. The average length of twenty cells which had been stimulated without being able to divide was $0.85 \mathrm{~mm}$., while one cell was found which measured $\mathrm{r} .85 \mathrm{~mm}$. in length.

A number of the filaments containing cells which had been unable to divide on account of the lack of potassium were carefully removed at 5 p.m., and placed in a watch-glass which contained some of their culture solution. During the night the temperature ranged from $15^{\circ}$ to $18^{\circ} \mathrm{C}$. When examined on the following day at 9 a.m. they were found to retain their former undivided condition.

In another experiment I tried the effect of transferring filaments from a culture in which sodium had been substituted for potassium, and in which the cells were consequently unable to divide, to a culture solution in which ammonium salts had been substituted for potassium. This transfer from 
one solution to another was made at the time the cultures were taken from the refrigerator, and just before submitting them to optimum conditions. Seven and one-half hours later, I found upon examination that a few cells had undergone division. Evidently there had been sufficient stimulus in merely transferring the cells to a different solution to induce a few cases of division, although no potassium salts had been given by the transfer. Whether the stimulus was of a physical or chemical nature remains to be determined.

The effect of adding a salt of potassium to cultures in which the cells were unable to divide in consequence of a previous lack of potassium was noted upon some of the material just described. At the time of removing the material from the refrigerator, a few drops of a 2 per cent. solution of potassium phosphate were added to one of the cultures. Seven and onehalf hours later I found that there had been some cell-divisions accomplished, but that many (perhaps a majority) of the cells had remained undivided, although they plainly showed the effect of the stimulus. This may have been due to one of two reasons. Potassium might have been necessary for certain of the initial processes and, lacking that, the whole mechanism of mitosis came to rest. Again, the failure to divide may have been due to lack of surplus nucleo-proteid material, and in the time of the experiment the cells were unable to use the new supply of potassium to form the requisite amount of nucleo-proteid.

\section{Experiments upon the rôle of phosphorus.}

A suitable supply of phosphorus is of fundamental importance for the continued activity of every living cell. Growth does not occur in the absence of phosphorus, because it is of primary importance for the formation of proteids. Koch and the writer have shown (Koch and Reed, '07) that when only an insufficient amount of phosphorus is present, the phosphorus of the nucleo-proteids shows practically no percentage decrease, while the water-soluble forms of organic and inorganic phosphorus show a relatively great decrease. The same conclusion may be drawn from the extensive analyses recently published by Wilfarth, Römer, and Wimmer ('05). They have shown that the amount of $\mathrm{P}_{2} \mathrm{O}_{5}$ in barley straw per hectare decreased from 29.04 kilograms on June 17 to 9.59 kilograms on July 27. The amount of $\mathrm{P}_{2} \mathrm{O}_{5}$ in the grain per hectare increased from 3.54 kilograms on June 17 to 29.84 kilograms on July 27 . These results indicate that the nuclein phosphorus of grains increases in amount at the expense of the water-soluble forms of phosphorus in the straw.

Phosphorus is also necessary for the formation of the glycero-phosphoric acids, of which lecithin is one of the best known, and which is present in nearly every living cell. The physiological importance of lecithin for plants has been pointed out by Loew ('99), Overton ('00), and others. 
Overton has concluded that lecithin plays an important rôle in the absorptive properties of the cell. He thinks that only those substances are absorbed which are soluble in the oily or fatty substances such as lecithin and cholesterin, which impregnate the cell-wall. Pfeffer remarks in this connexion that such impregnation may play an important part in regulating absorption, but, at the same time, the proteid constituents of the plasmatic membrane are also of importance. Lecithin is soluble to some extent in water, and may serve as a vehicle for the assimilation of fats. It is rather improbable that the chief function of lecithin is to serve for respiration, as Loew suggested. It may be pointed out that those tissues of animals which contain relatively large amounts of lecithin are not necessarily active agents in respiration.

Hydrodictyon died within two weeks after being transferred to a nutrient solution containing no phosphorus. The cells which died during the first few days of the experiment contained considerable starch, but where the cells died slowly the pyrenoids and their deposits of starch seemed to be consumed. Whether the cells died slowly because they were able to make use of the material of which the pyrenoids were composed, I was unable to determine.

When filaments of Spirogyra were cultivated in solutions which lacked phosphorus they showed the injurious effects at the end of three weeks. At that time many of the cells were dead, and the remainder showed evidence of greater or less injury. The contents of the dead cells were completely broken down; the nucleus having broken from its radiating strands of protoplasm was usually at the end or upon one of the lateral walls of the cell.

There appeared to be three well-marked stages in the death of Spirogyra cells in the solutions lacking phosphorus. In the first stage, the cell contents appeared cloudy, and the Marchi test usually showed that fats were present. This was undoubtedly due to the fact that the usual formation of lecithin was not going on, owing to the absence of phosphorus, and in consequence there was an accumulation of fats in the cells. In the second stage the chlorophyll bands became disarranged, either by taking a position nearly parallel to the long axis of the cell, or by rolling up in close spirals. In the third stage all green pigment disappeared from the chloroplasts, and the cell contents suffered complete disorganization. At the same time the filaments themselves were broken up in a very characteristic manner. Some time previous to the death of the filaments they had broken up into short rods composed of two or three cells, and, in many cases, the individual cells were entirely separated from neighbouring cells. The cells in this isolated condition appeared to suffer no more injury or to die no sooner than those which retained their normal relations. 
In the material studied there was no evidence that the absence of phosphorus interfered with the process of starch formation. Cells which had died as a result of the absence of phosphorus displayed distinct rings of starch in the pyrenoids, and there were numerous starch grains in chloroplasts which were so seriously injured that their green pigment had disappeared. It seems hardly probable that all of this starch can be accounted for by assuming that it is identical with that present when the plants were transferred to the phosphorus-free solution. I have previously described how the starch originally present in these forms disappeared when they were transferred to solutions lacking potassium. It seems plausible to believe that a portion of this starch had been formed after the plants were put into the phosphorus-free solutions.

The transformation of starch into water-soluble carbohydrates was seriously impaired in cells deprived of phosphorus. In its absence starch was transformed into unusual forms of carbohydrate. Some cultures of Spirogyra in phosphorus-free solution were kept in diffuse light at rather low temperature for four months. This treatment tended to prolong the life of the cells by lowering their activity. When, at the expiration of that time, the filaments were examined microscopically they showed no signs of growth, although most of the cells did not seem to have been seriously injured. In nearly all cases there was a considerable quantity of starch remaining in the cells. When they were submitted to the action of potassium iodide iodine solution for twenty to thirty minutes they showed the presence of erythrodextrin. In order to make sure that the reacting substance was really erythrodextrin, I placed several filaments of the alga in a watch-glass containing a weak solution of diastase. At the end of two and one-half hours the tests were inconclusive, but at the expiration of eighteen hours there was hardly a trace of erythrodextrin remaining in the cells which had lain in the diastase solution.

The formation of cellulose was increased in a striking manner in the same plants in which erythrodextrin was demonstrated. The normal thickness of cell-walls in the control cultures of Spirogyra was 5 or 6 microns, but when grown in the absence of phosphorus many cells possessed walls 10 and $\mathrm{I} 2$ microns thick. I also observed thickened cellwalls in Basidiobolus which was cultivated upon phosphorus-free media. It would appear in these cases that it was not possible for starch to be fully hydrolyzed, but instead that it was merely transformed into dextrin, which probably represents one of the stages in the hydrolysis of starch. It was also possible for starch to be changed to cellulose, probably its polymeric form.

The course of the carbohydrates in the cells living in deficient nutrient solution indicates quite clearly that the lack of phosphorus interfered with the production or action of the enzymes which normally convert starch 
into various saccharides. Loew and Bokorny ('87) reported that glucose occurs in demonstrable amounts in cells of Spirogyra during the process of conjugation, and also in cells which slowly perish in unfavourable conditions. It may be possible that these cells normally form glucose, and that its accumulation is due to the fact that the machinery of the cell is in no condition to make proper use of it.

The results of various experiments agree in showing the necessity of phosphorus for the production of proteids and proteid-like bodies. The injurious effect upon enzyme formation is, perhaps, analogous to the rapid disappearance of the water-soluble forms of phosphorus from the cell in cases of phosphorus-starvation observed by Koch and myself ('07). The diastase would probably be one of the first components of the cell to disappear, since, as I have shown in a former paper ('04), the production of enzymes is quickly influenced by external conditions.

The separation of the cells of the filaments from each other was probably brought about through conditions which dissolved the middle lamella of the cell-wall. The middle lamella, as first pointed out by Payen ('46), is mainly composed of calcium pectate, but in young unmodified cell-walls a considerable quantity of pectose is present, and a correspondingly smaller amount of calcium pectate. In the cell-walls under consideration, pectose undoubtedly forms a part of the middle lamella. Apparently the conditions brought about in the cell through the absence of phosphorus resulted in the formation of some substance in the cells (or in the culture-solutions), which dissolved the calcium pectate and pectose, and allowed the cells to separate. This question seems worthy of more extended study than I have been able to give it.

To study the rôle of phosphorus in germination I made several cultures of moss spores. Part of the cultures were made in the complete nutrient solution, and others in solutions containing all necessary elements except phosphorus. The spores were obtained from a species of Atrichum, and cultivated in solutions from March 9 to May ro. On the latter date the complete nutrient solutions contained large branched protonemata, which were developing buds and rhizoids. In the solutions lacking phosphorus there had been no germination of the spores.

With different solutions and different species of mosses, Schoene ('06) was able to germinate spores on phosphorus-free nutrient solutions. Funaria hygrometrica spores germinated, but produced only rhizoids in place of the normal protonema. Bryum caespiticium spores germinated on the deficient solutions, forming protonemata of an inferior size relative to the controls. The small protonemata grew for about ten days, and then began to turn brown at the apices. The injury would spread within a few days until the entire protonema was brown and all activity ceased.

The process of mitotic cell-division was studied in the absence of 
phosphorus in the same manner as described in the experiments where potassium was absent.

A large culture of Spirogyra, which had grown for thirty-five days in the absence of phosphorus was subjected to a temperature of $5^{\circ} \mathrm{C}$. during the night. At 9 the next morning it was placed in good light at a temperature of about $20^{\circ} \mathrm{C}$. Two hours later it was examined with a microscope to ascertain what effect the lack of phosphorus would have upon the processes of nuclear and cell division.

It was evident from the first that the tendency to divide was manifested by fewer cells than in experiments where only potassium was absent. The filaments in the phosphorus-free solutions were in a living condition, yet a comparatively small number of cells showed any elongation or growth of the cells similar to that noted in cultures where potassium was absent. This may have been due either to a lack of suitable materials for growth, or, what is more likely, to the lack of simpler soluble substances, which by their reactions could have supplied the energy necessary for mitosis. The few cells which showed a tendency to divide had elongated to approximately twice their length. The nuclei also were attenuated in the direction of the longer axis of the cell, but there were no cases of division to be found, although at the same time there were a great many dividing cells in the control cultures. Three and one-half hours after taking the material from the low temperature, I divided the material in which no mitoses were occurring into two portions. One portion was kept unaltered for a control, to the other I added a few drops of a 2 per cent. solution of potassium phosphate. At the end of an hour the material was examined, and I found that the addition of the phosphorus had enabled some of the cells, which had been previously stimulated, to accomplish the process of division. The culture to which no potassium phosphate had been added showed no cases of mitotic divisions.

On the whole the experiments go to establish the predominating importance of phosphorus for the metabolism of the cell. When, for example, spores containing a small amount of reserve materials were put into a solution lacking phosphorus they were not able to germinate. When living cells were transferred to phosphorus-free solutions they soon ceased to grow. When cells succeed in living for a time in the phosphorusfree solutions their metabolism is impaired, and abnormal products are formed.

\section{Experiments upon the rôle of calcium.}

Most green plants, except certain of the Cyanophyceae, appear to require a suitable supply of calcium for normal growth. Relatively small amounts of calcium appear to suffice for the nutrition of most plants. It will not be safe to make such broad claims for the necessity of calcium in 
plant growth, as some writers have done. Bruch ('02) has called attention to the fact that, aside from being unnecessary for Fungi and the lower Algae, it is quite toxic to certain swamp and aquatic plants.

The analysis of a plant usually shows that the greater part of the calcium is deposited in the stems and leaves, which at least suggests that it is concerned with the synthetic formation or transportation of organic products. Calcium forms a relatively small part of the seeds and fruits of most plants. The amount of calcium in diseased or etiolated leaves is less than in healthy leaves. Smith ('93), in his studies of peach 'yellows', gave the percentage of calcium in the ash of healthy leaves as 40.58 , and in the diseased leaves as 23.88 . In this connexion it may be proper to refer again to the results of von Portheim and Samec ('05). They found that in normal Phaseolus plants the amount of calcium was always greater than the magnesium, but that in etiolated plants the amount of calcium was often no greater than that of magnesium. All experimenters have observed that seedlings cultivated in solutions lacking calcium salts usually develop small leaves.

When I cultivated Spirogyra in a nutrient solution lacking calcium the chlorophyll soon showed signs of injury similar to that described by Bokorny ('95) and Loew ('99). The lobate margins were lost, and the broad bands became narrowed to a mere line. During the first stages of injury the pyrenoids contained some starch, but as the chloroplast sustained further injury the starch was less distinct. After seven weeks the chloroplasts became vacuolated and disorganized.

The chloroplasts of Zygnema likewise showed striking injuries when that alga was cultivated in a calcium-free solution. The delicate star-like form of the chloroplasts was lost because the radiating points were withdrawn. In cells which showed the most injury from lack of calcium the chloroplasts were contracted into irregular masses which ultimately became vacuolated. The application of iodine solution showed that each chloroplast contained considerable starch even when the injury was quite severe.

After Spirogyra had been deprived of calcium for two months only the smaller part of the cells remained alive, and they showed marked indications of injury. I noted in such cases that the apical cell of a filament was generally the first, and often the only one to show evidences of injury. In addition to the injury to the chloroplasts, already described, I found that these cells were partly filled with a dark substance which rendered them more or less turbid. The accumulation of this turbid material was usually greatest in the vicinity of the nucleus. Marchi's test showed that the substance causing turbidity was lecithin or some body closely related to the lecithins.

In the majority of cases I failed to obtain much evidence which bore 
directly on the antagonistic action of calcium and magnesium which was discovered by Bochm ('75) and investigated thoroughly by Loew ('92). In my study of the rôle of calcium in Vaucheria, some evidence was obtained upon this question which is conclusive enough, so far as it goes, to warrant mention in this place. On April 5 a series of cultures of this alga was -made in nutrient solutions lacking calcium and also in O.I per cent. solutions of calcium nitrate and of magnesium sulphate. The substitution for calcium salts in the formula of Beijerinck was made in two ways. In the first, magnesium chloride was substituted for calcium chloride, thus increasing the amount of magnesium about 50 per cent., and at the same time removing the antidoting agent, calcium. In the second, sodium chloride was substituted for calcium chloride. This solution may be considered as being quite different physiologically from the first because sodium, as was shown by the work of Kearney and Cameron ('02), acts as an antidote for magnesium. The filaments selected for these cultures were in a healthy growing condition, and contained a copious amount of oil droplets. In a few cases there were incipient zoosporangia at the tips of the filaments. At the end of eleven days there were evidences of injury to the plants in the solutions lacking calcium salts. The injury was found to be far greater in those solutions in which magnesium had been subsituted for calcium. There, many of the filaments were dead and broken up. The chloroplastids had lost their green pigment, and no oil droplets were to be found. The cultures in which sodium had been substituted for calcium contained material which was still living, although more or less injured. The chloroplastids were still green, and the protoplasm contained some oil droplets. In the control cultures there were numerous incipient oogonia and antheridia, but no signs of either were noted in the calcium-free solutions. I ultimately succeeded in keeping Vaucheria alive for seven weeks in cultures in which sodium had been substituted for calcium.

In the 0.1 per cent. solutions of calcium nitrate, the filaments were healthy and showed signs of growth by their numerous oil droplets and bright green colour. The incipient zoosporangia in these cultures had developed so far as to form the transverse walls separating the contents of the sporangium from the rest of the filament. The contents of the sporangia had, however, failed to develop zoospores. The filaments in this solution were developing sexual organs pari passu with the controls. In contrast, I found that all the filaments in the $\mathrm{O} \cdot \mathrm{I}$ per cent. solution of magnesium sulphate were dead.

It appears from these experiments that a large part of the injury was due to the toxic action of the magnesium, as well as to the absence of calcium. It seems reasonable to conclude that calcium is beneficial not only because of its value as a plant-food constituent, but on account of its power to antidote magnesium. This view is further supported by the 
result of experiments in which sodium was added to solutions in which calcium was omitted, for there the lack of calcium seemed to be much less severely felt by the plants.

The spores of Gymnogramme sulphurea were able to germinate and produce normal prothalli in the absence of calcium salts. At the end of three months in the calcium-free solutions the prothalli were in good vegetative condition, and their meristematic cells contained a moderate amount of starch. The most striking variation from the normal course of development was found in the solutions where magnesium had been substituted for the missing calcium. The prothalli in these solutions had made very good growth, and had developed a very large number of antheridia, but no prothallus was ever found which had formed an archegonium. The cultures were continued for a total period of five months, during which time the prothalli in the control cultures developed both antheridia and archegonia, and, in course of time, young sporophytes. The prothalli in these calcium-free solutions did not, however, produce any archegonia. The antheridia which they produced were entirely normal, and produced normal antherozoids.

It will be noted that these results have a similarity to those obtained by Prantl ('81) who cultivated fern prothalli on solutions lacking nitrogen. On nitrogen-free solutions he obtained only antheridia, but on complete nutrient solutions both antheridia and archegonia. The development of archegonia on the prothalli appeared to be closely related to the formation of meristematic cells. In the cases which I have studied, the appearance of archegonia did not seem to be necessarily conditioned by the development of meristem.

It may be mentioned, in passing, that the nuclei of different sex cells of ferns differ, according to Zacharias ('87), in their chemical nature, and to this may be related the disappearance of one sort of cells under special conditions. The male sex cells are rich in nuclein and contain small nucleoli. The nuclei of the female sex cells are poor in nuclein, but rich in proteid and contain one or more nucleoli, often of large dimensions.

There is an obvious correlation between the structure of the nucleus and its activity, chemical or otherwise. In an earlier paper (Reed '04) I have shown that in the secreting cells of germinating seeds the nucleoli become smaller and the chromatin greater in amount as the activity of the cells increases. The observations there recorded indicate that the substance making up the chromatin and nucleoli is identical, the two forms differing mainly in their activity (or lability). Upon this hypothesis the nucleoli represent the less active or potential condition, while the chromatin represents the active or kinetic condition. Applying this theory to the case in hand, we may say that the active (kinetic) nuclei of the antherozoidforming cells are able to obtain the materials from the incomplete solutions, 
and, perhaps, from the neighbouring cells, necessary for their existence and growth. The more sluggish nuclei of the incipient female sex cells being unable to obtain the necessary substances for growth and activity, did not develop far enough to form sexually mature cells.

Some instructive facts upon the rôle of calcium salts were obtained by studying the process of cell-division in filaments of Spirogyra in calcium-free solutions. The conventional method of submitting the cultures to a low temperature during the night in order to stimulate mitotic division was adopted. Cultures of Spirogyra which had grown for six weeks without calcium salts showed evidences of some injury, yet the nuclei were able to divide. The mitosis was found to be in progress in many cells one hour after the cultures were removed from the refrigerator. Three hours and forty minutes after removal from the refrigerator I found many instances of mitosis, some of which were approaching completion. So far as the substance of the nuclei themselves was concerned, the mitotic divisions appeared to be typical, but the new transverse cell-wall was frequently incomplete, and still more frequently was entirely lacking. The appearance of the cells closely resembled those described by Molisch ('95) under similar conditions. In the control cultures the mitoses were normal and had formed perfect cell-walls between the daughter nuclei.

In the growing region of the root, a similar effect upon the process of mitosis was noted. Stained sections of the roots of Zea Mais plants, which had grown in calcium-free solutions, showed a number of cases in which the transverse septum had not formed after the process of nuclear division was completed.

A similar incapacity to form cellulose was found in the case of an alga which was about to form the thick walls of the resting spore. A quantity of Spirogyra was in the initial stages of conjugation when put into cultures on June 30 . On July I3, when I examined the cultures I found that many of the filaments in the calcium-free solutions had succeeded in forming normal conjugating tubes, and that gametes had been produced. The most striking feature that I found was the case of conjugating cells which had fused to form a resting spore, but no cellulose wall was formed upon the surface of the plasmatic mass. In other respects the process of conjugation appeared to be normal, and I cannot explain the lack of cellulose formingpower unless it be caused by the lack of calcium salts.

The absence of calcium has been observed by several investigators to have a similar effect upon the power of the cell to form cellulose. It seems possible that some light might be shed upon the question by a consideration of the nature of the framework upon which the cell-wall is built. The middle lamella, as was first shown by Payen ('46), is composed of calcium pectate. Timberlake ('01) showed that the middle layer which appears after the splitting of the cell-plate in the later stages of mitosis may 
be considered as the initial middle lamella. This middle layer appears to be formed originally by deposition from the split halves of the cell-plate, which were in turn derived from thickenings on the kinoplasmic spindle fibres. It cannot be assumed, however, that the middle lamella consists only of the material first deposited from the young plasma membranes. We have evidence rather that it consists of the material first deposited by the plasma membranes plus a certain amount of material subsequently deposited in contact with the layers. The writer believes that the absence of new cell-walls after mitosis, in cells lacking calcium, indicates that the cells were unable to form the fundamental ' middle layer' of the cell-plate, and, in consequence, no cell was formed.

It appears from what has been said that the rôle of calcium differs in certain respects from that of the elements previously described. It differs quite widely from potassium and phosphorus in forming but a small proportion of the actual living substance of the plant. The functions which it performs are varied, but are none the less specific on that account, and its absence may affect some of the most vital activities of the plant. Calcium influences, in a remarkable way, processes and products into which it does not seem itself to enter, although it may be necessary for the formation of the zymotic and other agents which accomplish the results. It is now recognized that calcium salts act beneficially upon the soil mainly through their ability to bring about the proper physical and chemical conditions for growth without serving directly as a nutrient. It is entirely possible that it may so function inside of the plant in the living substratum.

A conspicuous example of how this function may be performed is in the formation of calcium oxalate. By precipitating the poisonous oxalic acid in an insoluble form, the juices of the plant are maintained in a proper condition of acidity for their most effective work. It was shown, for example, by Groom ('96) that diastase was unable to accomplish the normal conversion of starch to sugars in the presence of oxalic acid.

It seems probable from such work as that of Wehmer ('06) that the plant is not altogether able to regulate the production of oxalic acid, as Pfeffer believes. It is, however, undoubtedly able to regulate to some extent the amount of calcium absorbed, and hence to control in that way the processes into which calcium enters. It is altogether probable that the amount of calcium absorbed by the plant at different times would be found to be subject to wide variation.

The accumulation of lecithins and fatty substances, which I have found in the cell when calcium salts are lacking, is another example of an impaired activity in which we must believe that calcium only functions in a very indirect manner. The absence of egg cells and archegonia of the fern prothalli, and the inability of cells to form cellulose are other examples. 
4. Experiments upon the rôle of magnesium.

Magnesium is needed for the complete development of all plants. It is relatively more abundant in the fruits and seeds than in stems and leaves. A part of the functions of magnesium appear to be accomplished directly, and a part are indirectly performed, as in the case of calcium.

Magnesium has been assumed by Loew ('92) to play an important part in the assimilation of phosphorus as phosphoric acid. I have found that the amount of phosphorus present influences the functioning of the magnesium and vice versa.

Since the spores of the mould fungi are quite rich in lecithins and oils, they afford a suitable object of experimentation in investigating such questions. Some experiments were conducted upon spore formation in Aspergillus niger with the purpose of obtaining some light upon this question. It was not possible to exclude entirely the magnesium or the phosphorus from these experiments, because an insufficient amount of mycelium would have been obtained. The formula for the nutrient solution was that used for cultivating Basidiobolus and described on a previous page. No agar agar was added since Aspergillus grows well upon the surface of a liquid medium. The amount of phosphorus was reduced to fractional parts of the normal ratio ; the amount of magnesium was reduced in some experiments, and increased in others.

In the first experiment the phosphorus was reduced to one-fifth the normal amount, and the magnesium increased to nearly three times the normal, thus making the ratio of magnesium to phosphorus about fifteen times as great as in the control solution. The mycelium produced on $100 \mathrm{cc}$. of this modified solution was slightly better than that produced on the control, weighing $1.55 \mathrm{~g}$. in comparison with $1.20 \mathrm{~g}$. for the control. The amount of spore-formation was judged by the eye to be 10 per cent. of the control cultures. A second experiment was made to determine the effect of decreasing the amount of phosphorus and magnesium present, while keeping the ratio equal to that of the control culture. One-tenth the normal amount of each element was used. The mycelium which grew on this solution produced approximately 50 per cent. as many spores as the controls, and approximately five times as many as upon the solutions in which magnesium predominated. These results are interpreted to mean that the surplus of magnesium in the first experiment was unfavourable to the development of spores. The particular point which seems worthy of emphasis is that in the first experiment there was twice as much phosphorus present as in the second; yet, on account of the great predominance of magnesium, conditions were not so favourable for sporeformation as in the second experiment. In other words the maintenance 
of a proper ratio between magnesium and phosphorus was of more importance than the absolute amount of phosphorus present.

The filaments of Spirogyra which were cultivated in solutions lacking magnesium continued to live for some time, but showed characteristic injury. At the end of five weeks I found the chlorophyll bands disarranged and forming a more or less compact mass near the centre of each cell. A typical cell is represented in Fig. 2. In the cells which showed less injury, the nuclei were imprisoned within the irregular mass of chloroplasts ; but in the more severely injured cells the nuclei had often lost their protoplasmic fibrillae and could be found in various abnormal positions in the cells. The state of affairs would seem to indicate that the fine strands of protoplasm radiating from the nucleus to the chloroplasts had been acted upon by some agent which caused them to contract simultaneously. In

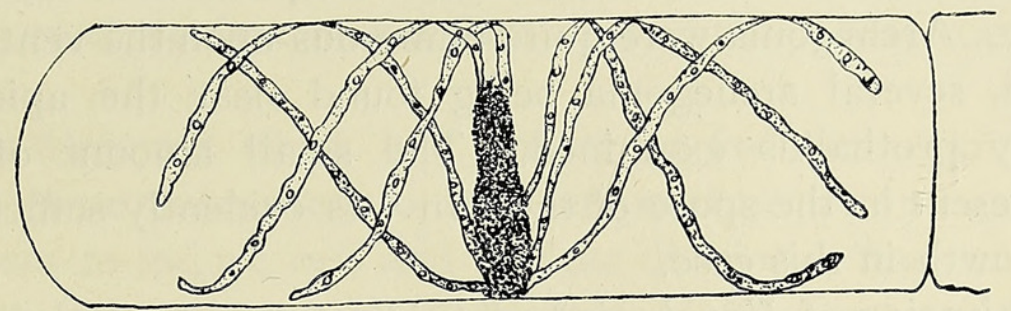

FIG. 2. Spirogyra cell grown six weeks in magnesium-free solution. Shows the contraction of the chloroplasts away from the ends of the cell. Drawn from a living cell mounted in water.

most cases the contraction had been violent enough to draw the chlorophyll bands away from the ends of the cell, and to make a more or less compact mass in the centre of the cell.

From a study of their behaviour it seems correct to ascribe the effects produced to the calcium present which is, in the deficient solutions, unbalanced by magnesium. Such an effect has at least an analogy, and perhaps more, in the effect of calcium on the muscle of animals. It has been shown by Greene ('99) and by Howell ('01) that strips of heart muscle will give a characteristic series of beats when placed in an isotonic solution of sodium chloride. A solution of calcium chloride, on the contrary, increases the tonus of the muscle which may pass into a state of permanent rigor from which recovery is impossible.

The chlorophyll bands in these cells were narrow, similar in many respects to those in cells deprived of calcium salts. The characteristic lobed margins were also lacking. In some cases the chloroplasts had been so sharply bent that they were broken at the centre, thus giving two groups of chloroplasts with a very narrow space between them. The pyrenoids stood out distinctly and appeared to be nearly, if not fully, normal size. There was an absence, however, of accessory pyrenoids (or dark staining bodies) similar to those appearing in the chloroplasts of the control plants. 
By the use of stained preparations I was able to study the form of the nuclei in cells which showed signs of injury. I was unable to observe the shrunken nuclei which Bokorny ('95) observed under similar conditions. On the contrary the nuclei presented an unusually firm, even contour, because most of them had lost the enveloping layer of protoplasm with its radiating strands.

On account of the peculiar effect which the absence of calcium had upon the development of sexual organs on the prothalli of Gymnogramme sulphureum, it may be of interest to note the effect of the absence of magnesium. The spores of that fern when sown upon the surface of a nutrient solution germinated and grew very well. At the expiration of three months there were large numbers of well-developed prothalli on these solutions. A considerable quantity of starch was present in the younger cells on the lateral lobes, but less was present in the cells near the apical notch. Archegonia were quite numerous upon the ventral surface of the prothalli, several archegonia being found near the apical notch on almost every prothallus examined. The small amount of magnesium originally present in the spore of the fern was evidently sufficient for quite extensive growth in this case.

The cultivation of Vaucheria in deficient nutrient solutions is, generally speaking, rather difficult. Many of my attempts met only with failure, but in the case of magnesium-free solutions, I met with somewhat better success. Material was used which had grown for two months in the laboratory. The filaments appeared to be in good growing condition, containing both chloroplasts and oil drops throughout. A few of the filaments were beginning to form oogonia, and judging from their form the species seemed to be $V$. gemmata. The cultures stood upon the sill of a west window, at room temperature from January I 7 to February 7. Upon the last-named date I found that the filaments in the magnesium-free solutions were entirely without oil globules, although oil globules were abundant in the filaments in the control solutions. Otherwise the filaments in the magnesium-free solutions appeared perfectly healthy and not injured. Filaments taken from the same source were growing in solutions lacking calcium salts without showing any diminution in the number or size of the oil globules they contained. It seems that there is no escape from the conclusion that there is an intimate relationship between the presence of magnesium and the formation of vegetable oils. Such a relation was suggested by Loew ('99), and he called attention to the fact that analyses show that oil-containing seeds like those of flax and cotton contain much more magnesium than the starch-containing seeds, like those of the cereals. Aso ('01) has published analyses of the spores of Aspergillus oryzae which show that those spores contain a moderately large amount of magnesium. This fact seems of importance because we know that the spores of the Fungi 
store most of their reserve food in the form of oil. Still more important is the work of Sullivan ('05) who showed that, in order to form lipochromes to advantage, certain bacteria required the presence of magnesium sulphate and a phosphate, preferably potassium phosphate. The presence of relatively large amounts of magnesium in oil-forming seeds and spores confirms what was said on a previous page regarding the necessity of magnesium for the assimilation of phosphorus. This necessity is the more evident when we remember that the formation of fat is usually preceded or accompanied by the formation of lecithin.

The inability of Vaucheria cells to form oils in the absence of magnesium salts seems to prove that the foregoing hypothesis is the correct one. It seems possible that this function of magnesium may be its most important one. Probably all cells require at least a small amount of fatty material for the performance of all their functions. In the formation of these fats magnesium undoubtedly plays an important part.

Spirogyra filaments which had grown for five weeks in the absence of magnesium were submitted to low temperature in the same manner as other cultures to induce cell and nuclear division. The nuclei of these cells appeared to respond to the stimulus more slowly than any of the others had done. In the cells which showed greatest injury no response whatever was shown. Three hours and forty minutes after being placed in optimum conditions some cells and nuclei showed the phase of elongation presaging division. It was nine hours after removing the cultures from the refrigerator that I found the first cases of actual division. The divisions appeared to be normal in every way, and left no doubt in my mind that the nuclei of Spirogyra are able to divide mitotically in the absence of magnesium salts.

\section{Discussion of Results.}

Before proceeding further it may be in place to discuss the nature of the conclusions which may be legitimately drawn from experiments like those related in the foregoing pages. Since many of the methods which I have employed are capable of quite general application, it seems probable from the results obtained that they can be successfully applied to the study of certain types of physiological questions.

Microchemical methods are observational in character, and, like most purely observational methods, can yield only qualitative results. When possible, they should be followed by quantitative work. This does not mean that qualitative methods of study are of less value; on the contrary, qualitative methods, being observational in character, are of the greatest value in all biological work, and will probably continue so for some time. A valuable feature of microchemical methods in physiological 
research is that they enable the observer to localize processes and products of cell metabolism. In consequence, one may expect to learn more precise facts concerning the function of the different organs of the cell under different conditions. In this respect the study of physiology is put upon a cytological basis. A trend in this direction may be expected in the future, just as morphology has become so largely a cytological study. As more methods are developed by means of which qualitative tests may be made upon the cell, the use of such observations will increase.

Reverting to what has been said concerning the specific rôle of the various elements studied, it may be pointed out that they possess common characteristics as well as specific differences.

The absence of no one essential element seems to be prohibitive of spore germination, as a general rule. Of course the growth of the sporelings was never as good in the incomplete solutions as in the complete solutions used as controls. In other words, the slight amounts of the essential elements in the spore stored as reserve food are sufficient to sustain growth for a time in an environment which lacks one of the essential elements. The resulting germination or growth in any such case is modified by characters apparently belonging to individual species.

The most easily recognizable functions of the essential elements, and the most capable of being understood, are those in which the element in question is directly utilized in some form in the synthetic formation of some organ or substance in the cell. In such processes it is usually not difficult to demonstrate that the element in question enters directly into some compound or organ of the cell. As an illustration of such a function, the rôle of phosphorus in the formation of lecithin may be given. Unless the radical of phosphoric acid be present, there is no way of uniting the glycerofatty acids to the cholin group. Hence, in the absence of phosphates, fatty substances accumulate in the cell. The same is true of the reason for the necessity of phosphorus in the formation of nucleoproteids. All chemists are agreed that phosphorus holds an important position in the grouping of the elementary substances which make up the nucleins. The failure of the nuclei of Spirogyra to divide in solutions lacking phosphorus can therefore be readily understood, upon the grounds that a necessary element in the formation of nucleoproteids was lacking.

A second class of functions which it has been shown that the essential elements are capable of performing, are those in which the element does not itself enter into the composition of the end product of the reaction. In such cases the essential element may possibly be looked upon as a necessary catalyser, or as a dominating factor in bringing about proper conditions for the specific reaction to take place. It is probable that the greater part of the functions which any element performs in the plant belong to this class. 
It has been shown, for example, that potassium is necessary for starch formation, and calcium for starch transportation; yet neither of these elements enters into the composition, either of starch, or of the compounds which arise as partial products in the formation of starch. Where phosphorus was lacking, there was an abnormal production of cellulose from starch, and in some cases erythrodextrin was formed from the starch. These effects may very probably have been due to the absence of the proper enzyme, which in normal cells converts starches to the various sugars. In turn the absence of the phosphorus may have been responsible for the non-formation of the requisite enzyme. In such an event, it shows that the influence of the element in question is an indirect one.

The fact that there is reason to believe that the individual elements may control the formation of certain catalytic agents, leads up to the question whether the individual elements may not themselves act as catalytic agents in certain processes. Such reactions have been more graphically worked out for the action of toxic bodies upon protoplasm than for the reaction of nutrient substances.

The results also give evidence to show that the value of an element, or of a compound, may consist, in part, in its ability to act as a carrier of certain ions or radicals. Magnesium appears to be necessary in some cases for the formation of oils. It is not probable that magnesium enters into the composition of the oils in any form. It acts rather as a carrier of some radical, probably that of phosphoric acid, which is necessary for the formation of lecithins. Later these lecithins may be split up with the formation of fats.

Another indirect function which some elements may perform may be designated as an 'antagonistic' or 'antidoting' function. Calcium and sodium, for example, appear to be of value in many cases because of their power to neutralize or overcome the otherwise harmful effect of magnesium. Concerning the real method by which the antidoting is accomplished we have little exact knowledge. Judging from the results which have been obtained, the beneficial action of these elements seems to be associated with biological processes, and the value of any antidoting agent will probably vary with different species of plants. It is not out of place, however, to note that an extended study of the reactions of the essential elements with the products of cellular metabolism might afford data of interest in this regard. It is known, for example, that calcium hydroxide will precipitate lecithin, but if sodium chloride be present, no precipitation will occur.

In the present paper no attempt has been made to study the value of the different essential elements or their compounds as sources of energy. A study of that question belongs more properly in the domain of chemistry than the present investigation has been carried. The value of the elements 
in this connexion has been well pointed out by Wilfarth, Römer, and Wimmer ('05).

The character of the changes which are produced when one of the essential elements is lacking seems worthy of attention. In the experiments which have been described above, no case was found in which the absence of an essential element caused serious modification in the form or structure of the strictly living parts of the cell. Careful observations were made upon different plant cells with special reference to any modifications of the form of the nuclei, of the amount, form, or arrangement of the chromosomes. No changes could be discovered which indicated in any way that the lack of an element caused any modification of form or structure in the strictly living organs of the cell. My results appear to be quite comparable to those obtained by Klemm ('95) in a study of the disintegration of the cell organs following the action of strong physical and chemical stimuli. Klemm found that, although deep-seated changes were produced in the plasmatic organs of the cell, often no morphological evidence of the injury could be found until death was close at hand. The changes of form or structure which were brought about by the absence of one of the essential elements were always observed in the non-living parts of the cell, e.g. cell-wall, chlorophyll, starch, oil, \&c. For this reason those cells were most profitable for study which contained the most highly differentiated non-living bodies. The cells of the root-tips of higher plants do not contain non-living elements other than the cell-wall, consequently the study of those cells was comparatively unfruitful. In cells like those of Spirogyra which are quite highly organized, but exhibit no physiological division of labour, the lack of an essential element is most noticeable in a microchemical study. It should not be concluded from these statements, that the lack of an essential element has no effect upon the seats of the vital processes. In this connexion it is proper to call attention to the teratological phenomena observed by Molliard and Coupin ('03). These investigators found that when Sterigmatocystis (Aspergillus) nigra was grown in the absence of potassium, the normal form of conidial apparatus disappeared. In place of the normal conidiophores, variable outgrowths appeared.

On the other hand, it is more than probable that the modifications of the non-living structures of the cell are the expressions of more deeplyseated changes in the activities of the living mechanism. When at length the absence of an essential element becomes serious enough to stop or reverse the normal course of activity, all activity ceases, i. e. death ensues. 


\section{Summary.}

I. The algae studied thrive best in artificial cultures which remain neutral or slightly acid in reaction. The phanerogams studied thrive better in a solution which remains neutral or slightly alkaline in reaction.

2. Potassium salts were found necessary for the germination and growth of certain mosses. When a certain sub-minimal amount of potassium was present, there was some evidence that certain moss spores could germinate and avail themselves of sodium during the embryonic stages of development.

3. In all green plants studied, potassium was essential for starch formation.

4. Mitotic cell division did not take place without a suitable supply of potassium, although a certain amount of growth by stretching was possible. The transfer of stimulated cells from one potassium-free solution to another potassium-free solution of slightly different composition enabled a few cells to divide.

5. The lack of phosphorus seemed to be more injurious to the cells studied than the lack of any other element.

6. Cells in a state of phosphorus starvation first lose the soluble phosphorus complexes; later the injury extends to the strictly living organs of the cell, finally resulting in its death.

7. Phosphorus appears to be more closely connected with carbohydrate transformation than with the origin of those substances. In the absence of phosphorus abnormal transformations occurred.

8. In the absence of phosphorus no mitotic divisions were possible. Cells which had lived for some time in the absence of phosphorus were difficult to stimulate to divide.

9. Calcium appears to be necessary for the activity and growth of the chlorophyll and chlorophyll-containing organs.

IO. One of the most important functions of calcium seems to be the antidoting power it possesses for overcoming the bad effects of magnesium. There is evidence that the same function may be performed in part by sodium.

II. Antheridia were produced in large numbers on Gymnogramme prothalli cultivated in solutions lacking calcium, but archegonia were not found.

12. Cell nuclei were able to divide mitotically in the absence of calcium salts, but new cell-walls were imperfectly formed, if at all. The inability to form cellulose was also exhibited by the zygotes of Spirogyra.

13. Spore formation in Aspergillus niger was more abundant when 
magnesium and phosphorus were present in the ratio of the normal culture solution. An excess of magnesium over phosphorus was detrimental to spore formation.

I4. Magnesium salts were necessary for the continued health and activity of the chloroplasts.

I5. Oil was not formed in Vaucheria when grown in the absence of magnesium.

16. The nuclei of Spirogyra were able to divide mitotically when no magnesium salts were furnished, although the process was somewhat retarded.

I7. The essential elements studied appear to function in two ways :$(a)$ as component parts of cell structures or fluids ; and (b) as indirect agents in causing less understood physical or chemical conditions necessary for the proper functioning of the cell, whether as carriers of other ions, or as specific antidoting agents.

I8. The non-living parts of the cell, e. g. cell-wall, starch granules, or oil globules, are the only ones visibly modified by the lack of an essential element. The strictly living portions of the cell did not manifest any morphological changes until they were killed.

\section{BIBLIOGRAPHY.}

ARBER, E. A. N. ('01 A): On the effect of salts on the assimilation of carbon dioxide in Ulva latissima. Ann. Bot., xv, 39, I90I. $\mathrm{xv}, 669$, I90I.

Aso, K. ('01): The chemical composition of the spores of Aspergillus oryzae. Bull. Coll. Agr., Tokyo, iv, 8I, I90I.

Becquerel, P. ('04): Sur la germination des spores d'Atrichum undulatum et d'Hypnum velutinum et sur la nutrition de leurs protonémas dans des milieux stérilisés. Compt. rend. acad. sci., cxxxix, 745,1904 .

Benecke, W. ('07): Untersuchungen über den Bedarf der Bakterien an Mineralstoffen. Bot. Zeit., lxv, I, 1907.

Berthelot and André ('88): Sur le phosphore et l'acide phosphorique dans la végétation. Compt. rend. acad. sci., cvi, 7I I-7I 6, I 888 .

Birner and Lucanus ('66): Wasserkulturversuche mit Hafer. Landw. Versuchsst., viii, I28-177, I 866.

Bовнм, J. ('75): Ueber den vegetabilischen Nährwerth der Kalksalze. Sitzber. d. Wiener Akad. d. Wiss., lxxi, 287-304, I875.

Bokorny, Th. ('95): Ueber den Einfluss des Calciums und Magnesiums auf die Ausbildung der Zellorgane. Bot. Centralbl., lxii, I, I895.

Bouilhac, R. ('94): Influence de l'acide arsénique sur la végétation des algues. Compt. rend. acad. sci., cxix, $929, \mathrm{I} 894$.

Breazeale, J. F. ('05): Effect of the concentration of the nutrient solution upon wheat cultures. Science, xxii, I 46,1905 .

('06): The relation of sodium to potassium in soil and solution cultures. Jour. Amer. Chem. Soc., xxviii, $1013,1906$. 
BruCH, P. ('02) : Zur physiologischen Bedeutung des Kalziums in der Pflanze. Landw. Jahrb., $\mathrm{xxx}, \mathrm{I} 27-144,1902$.

Clark, J. F. ('01) : On the toxic value of mercuric chloride and its double salts. Jour. Phys. Chem., v, 289, I901.

Dassonville, Ch. ('98): Influence des sels minéraux sur la forme et la structure des végétaux. Rev. Gén. Bot., x, pp. 15, 59, 102, I61, 193, 238, 289, 335, 1898.

Davy, Sir Humphrey ('13) : Elements of Agricultural Chemistry. Philadelphia (published in), I $82 \mathrm{I}, \mathrm{p} .3 \circ 4$.

DORSET, M. ('03): The desirability of phosphates as an addition to culture media for tubercle bacilli. 2oth Ann. Rep. Bureáu of Animal Industry, U.S. Dept. Agr., I $9 \circ 3$.

DugGar, B. M. ('06) : The relation of certain marine algae to various salt solutions. Trans. St. Louis Acad. Sci., xvi, 473-489, 1906.

GAunersdorfer ('87): Das Verhalten der Pflanze bei Vergiftungen speziell durch Lithiumsalze. Landw. Versuchsst., xxxiv, I 7 I-206, 1887 .

Grafe, V. and Portheim, L. v. ('06): Untersuchungen ïber die Rolle des Kalkes in der Pflanze. Anz. k. k. Akad. Wiss. Wien, math.-nat. Kl., xviii, 324, I906.

Greene, C. W. ('98): On the relation of the inorganic salts of the blood to the automatic activity of a strip of ventricular muscle. Am. Jour. Physiol. ii, 82, 1898 .

Groom, P. ('96): Preliminary note on the relation between calcium and the conduction of carbohydrates in plants. Ann. Bot., x, 9I-96, 1896 .

Halliburton and Mott ('02): The chemistry of nerve degeneration. Phil. Trans. Roy. Soc., London, B cxciv, 437 , I 902 .

Hammarsten, O. ('96): Ueber die Bedeutung der löslichen Kalksalze für die Faserstoffgerinnung. Zeitsch. f. physiol. Chemie, xxii, 333-395, 1896.

Haselhoff, E. ('93): Versuche über den Ersatz des Kalkes durch Strontian bei der Pflanzenernährung. Landw. Jahrb., xxii, 85 I, 1893 .

Hellriegel, H. ('67) : Ann. d. landw. Wochenbl., vii, 299, 1867.

Hellriegel, Wilfarth, Römer, and Wimmer ('98): Vegetationsversuche iiber den Kalibedarf einiger Pflanzen. Arbeiten deutsch. landw. Gesell., Heft xxxiv, I898.

Holzner, G. ('67) : Ueber die physiologische Bedeutung des oxalsauren Kalkes. Flora, 1, 497, I867.

Howell, W. H. ('01) : An analysis of the influence of the Sodium, Potassium, and Calcium salts of the blood on the automatic contractions of heart muscle. Am. Jour. Physiol., vi, I $8 \mathrm{I}$, I90I.

KeARney and Cameron ('02): Some mutual relations between alkali soils and vegetation. Report 7I, U.S. Dept. Agr., 1902.

KLebs, G. ('96) : Die Bedingungen der Fortpflanzung bei einigen Algen und Pilzen. Jena, I896.

KL.emm, P. ('95): Desorganisationserscheinungen der Zelle. Jahrb. wiss. Bot., xxviii, 627 , I895.

Knop, W. ('81) : Untersuchungen über die Ernährung der Pflanze. Blomeyer's Ber. v. Landw. Inst. zu Leipzig, I88 I, pp. 3I, 5I. Abstr. in Biedermann's Centralbl. f. Agrikulturchem., x. $322, \mathrm{I} 88 \mathrm{I}$.

Koch, W. and ReEd, H. S. ('07): The relation of extractive to protein phosphorus in Aspergillus niger. Jour. Biol. Chem., iii, 49, I907.

Конn, E. ('05) : Zur Biologie der Wasserbakterien. Centralbl. f. Bakt., Abt. 2, xv, 690, 71 †, 1905.

Kraus, G. ('97) : Ueber das Verhalten des Kalkoxalats beim Wachsen der Organe. Flora, lxxxiii, 54, I 897 .

KRönig, B. and PAUL, Th. ('97): Die chemischen Grundlagen der Lehre von der Giftwirkung und Desinfection. Zeitsch. f. Hygiene u. Infect., xxv, I, I897.

Livingston, B. E. ('07): Further studies on the properties of unproductive soils. Bull. 36 , Bur. Soils U. S. Dept. Agr., 1907.

LoEB, J. ('06): The stimulating and inhibitory effects of magnesium and calcium upon the rhythmical contraction of a jelly-fish (Polyorchis). Jour. Biol. Chem., I, 427-436, 1906.

LoEw, O. ('91) : Ueber die physiologischen Functionen der Phosphorsäure. Biol. Centralbl., xi, 273,1891 .

('92): Ueber die physiologischen Functionen der Calcium und Magnesiumsalze im Pflanzenorganismus. Flora, lxxv, 368-394, 1892.

('98): Ueber die physiologischen Functionen der Calciumsalze. Bot. Centralbl., lxxiv, $25 \%, 1898$. 
Loew, O. ('98 A): Zur Frage der Vertretbarkeit von Kaliumsalzen durch Rubidiumsalze bei niederen Pflanzen. Bot. Centralbl., lxxiv, 202, 1898.

('99): The physiological rôle of mineral nutrients. Bull. 18, Div. Veg. Phys. and Path., U.S. Dept. Agr., 1899.

Loww, O. and Bokorny, Th. ('87): Chemisch-physiol. Studien iiber Algen. Journ. f. prakt. Chemie, xxxvi, 272,1887 .

('89): Ueber das Verhalten von Pflanzenzellen zu stark verdünnter alkalischer Silberlösung. Bot. Centralbl., xxxix, $369,1889$.

Lyon, E. P. ('04): A biological examination of distilled water. Biol. Bull., vi, I98, I904.

MAYER, A. ('69): Untersuchung über d. Alkoholgärung, 1869, p. 44.

MOLliaRd and Coupin ('03): Sur les formes tératologiques du Sterigmatocystis nigra privé de potassium. Compt. rend. acad. sci., cxxxvi, 1695,1903 .

Molisch, H. ('95) : Die Ernährung der Algen, I. Abh. Sitzungsb. Akad. Wien, math.-nat. Klasse, civ; Abt. I, 783, I895.

('96): Die Ernährung der Algen, II. Abh. Sitzungsb. Akad. Wien., math-nat. Klasse, cv ; Abt. I, $633,1896$.

Monnier, A. ('05): Les matières minérales et la loi d'accroissements des végétaux. Thèse, Genève, I $905, \mathrm{pp} .37$.

Moore, G. T. ('03): Methods for growing pure cultures of algae. Jour. App. Microscopy, vi, $2309^{-2314}, 1903$.

Nobbe ('70): Ueber die organische Leistung des Kalium in der Pflanze. Landw. Versuchsst., xiii, 399,1870 .

Osterhout, W. J. V. ('06): On the importance of physiologically balanced solutions for plants. Bot. Gaz., xlii, $127,1906$.

Overton ('00): Studien iiber die Aufnahme der Anilinfarben durch die lebende Zelle. Jahrb. wiss. Bot., xxxiv, 669 , 1900.

PAYEN ('46): Recueil des savants étrangers, ix, I48, i 846.

Pigorini, L. ('07) : La diminuzione della tossicità del nitrato di argento trat tato con tiosulfato sodico e l'azione della luce su questo fenomeno. Atti R. Accad. Lincei, Cl. sci. fis. nat. mat. (5), XVI, (I), 359, 1907.

Von PoRTheim and SAMEC ('05): Ueber die Verbreitung der unentbehrlichen anorganischen Nährstoffe in den Keimlingen von Phaseolus vulgaris. Flora, xciv, 263, 1905.

Pranti, K. ('81) : Beobachtungen über die Ernährung d. Farnprothallien und der Vertheilung d. Sexualorgane. Bot. Zeit., I88I, p. 753 .

RaCiborski, M. ('96): Ueber den Einfluss äusserer Bedingungen auf die Wachstumsweise des Basidiobolus ranarum. Flora, $1 \mathrm{xxxii}, 107-132,1896$.

Raulin, J. ('69): Études chimiques sur la végétation. Ann. d. sci. nat. (5), xi, 93, I869.

v. Raumer ('83): Calcium und Magnesium in der Pflanze. Landw. Versuchsst., xxix, 253-280, 1883 .

v. Raumer and Kellermann ('80): Ueber die Function des Calciums im Leben der Pflanze. Landw. Versuchsst., xxv, $25,1880$.

REED, H. S. ('04): A study of the enzyme secreting cells in the seedlings of Zea Mais and Phoenix dactylifera. Ann. Bot., xviii, 267 , 1904 .

Saussure, Theodore DE ('04): Recherches chimiques sur la végétation. Paris, $1804, p p .327$.

Schimper, A. F. W. ('88): Ueber Kalkoxalatbildung in den Laubblättern. Bot. Zeit., xlvi, 65,8 I, 97, I I 3, I 29, I 45, I 888 .

('90): Zur Frage der Assimilation der Mineralsalze durch die grüne Pflanze Flora, lxxiii, 207, 1890 .

Schoene, K. ('06): Beiträge zur Kenntniss der Keimung der Laubmoossporen und zur Biologie der Laubmoosrhizoiden. Flora, xcvi, 276, 1906.

Schreiner, O. and Reed, H. S. ('07) : Some factors influencing soil fertility. Bull. 40, Bur. Soils. U. S. Dept. Agr., 1907.

Sestini, F. ('91): Esperimenti di vegetazione del frumento con sostituzione della glucina alla magnesia. Le Staz. Agrar. Ital., xx, 256, 189i. See Centralbl. f. Agrikulturchem., I890, p. 464 , and 1891, p. $55^{8}$.

Smith, E. F. ('93): Experiments with fertilizers for the prevention and cure of peach yellows. U. S. Dept. Agric. Div. Veg. Path. Bull. 4, 1893. 
S'rohmann, F. ('62) : Ueber einige Bedingungen der Vegetation der Pflanzen. Ann. d. Chem. u. Pharm., cxxi, $285-338$, I862.

Suldivan, M. X. ('05): Synthetic culture media and the biochemistry of bacterial pigments. Jour. Med. Research, xiv, 109-160, I905.

Suzuki, U. ('00): Can strontium and barium replace calcium in phanerogams? Bull. Coll. of Agr. Tokyo, iv, 69, I900.

Timberlake, H. G. ('01): The development and function of the cell-plate in higher plants. Bot. Gaz., xxx, 73, I54, I90I.

True, R. H, and Gies, W. J. ('03) : On the physiological action of some of the heavy metals in mixed solutions. Bull. Torr. Bot. Club., xxx, 390, 1903.

VilLe, G. ('60): De l'importance comparée des agents de la production végétale. La soude peutelle remplacer la potasse? Compt. rend. acad. sci., li, 437, I860.

('61): De l'importance comparée des agents de la production végétale. Des composés phosporés utiles pour la végétation et des composés phosporés qui ne le sont pas. Compt. rend. acad. sci., liii, $83_{2}$, I 86 I.

Wehmer, C. ('91) : Die Oxalabscheidung im Verlaufe der Sprossentwickelung von Symphoricarpus racemosus. Bot. Zeit., xlix, I49-194, I89I.

('06) : Die Bildung freier Oxalsäure durch Aspergillus niger. Ber. d. dentsch. Bot. Gesell., xxiv, $38 \mathrm{I}-384$, I 906 .

Wheeler, H. J. ('05): Plant peculiarities as shown by the influence of Sodium salts. Bull. I04, Rhode Island Agr. Exp. Sta., 1905.

Wilfarth, Römer, and Wimmer ('05): Ueber die Nährstoffaufnahme der Pflanzen in verschie. denen Zeiten ihres Wachstums. Landw. Versuchsst., lxiii, I-70, 1905.

WinOgRADZky ('84): Ueber die Wirkung äusserer Einfliisse auf die Entwickelung von Mycoderma vini. Bot. Centralbl., $\mathrm{xx}, 165,1884$.

Wlassak, R. ('98): Die Herkunft des Myelins. Archiv f. Entwickelungsmechanik, vi, 453, I898.

Wolf, W. ('64) : Die Saussure'schen Gesetze der Aufsaugung von einfachen Salzlösungen durch die Wurzeln der Pflanzen. Landw. Versuchsst., vi, 203-230, I864.

Wolf, G. ('68): Bericht uiber die in den Jahren 1866 und I 867 ausgefuhrten Vegetationsversuche in wasseriger Lösung der Nährstoffe. Landw. Versuchsst., x, 349-379, I868.

Yermakov, V. ('05): Correlation between calcium salts and the assimilation of nitrate nitrogen. Russ. Jour. Expt. Landw. vi, 403-43 I, I905; Rev. in Exp. Sta. Rec. xvii, I I 44, 1906.

Zacharias, E. ('87) : Beiträge zur Kenntniss des Zellkerns und der Sexualzellen. Bot. Zeit., xlv, 280,1887 . 


\section{$2 \mathrm{BHL}$ Biodiversity Heritage Library}

Reed, Howard S. 1907. "The value of certain nutritive elements to the plant cell." Annals of botany 21, 501-543.

https://doi.org/10.1093/oxfordjournals.aob.a089152.

View This Item Online: https://www.biodiversitylibrary.org/item/235747

DOI: https://doi.org/10.1093/oxfordjournals.aob.a089152

Permalink: https://www.biodiversitylibrary.org/partpdf/318889

\section{Holding Institution}

Smithsonian Libraries

\section{Sponsored by}

Biodiversity Heritage Library

\section{Copyright \& Reuse}

Copyright Status: Not in copyright. The BHL knows of no copyright restrictions on this item.

This document was created from content at the Biodiversity Heritage Library, the world's largest open access digital library for biodiversity literature and archives. Visit BHL at https://www.biodiversitylibrary.org. 